\title{
The Belgian Constitution: The Efficacy Approach to European and Global Governance
}

\author{
Patricia Popelier and Catherine Van de Heyning
}

\begin{abstract}
The Belgian Constitution dates back to 1831 but became more prominent with the introduction of the Constitutional Court in 1980. While initially tasked with adjudication of federal competences, the Court gradually turned into a fundamental rights court. The protection of fundamental rights is predominantly based on the ECHR. The Belgian constitutional system demonstrates a singular openness towards international influences and, in particular, the European integration project. A monist approach, adopted by the Supreme Court in 1971, ensures the smooth implementation and priority of international and EU law, whereas only few instruments exist to temper their impact on constitutional values and fundamental rights or to ensure legitimacy. The disintegration of the Belgian State weakened the concept of national sovereignty, referendums for the approval of treaties are unconstitutional, and ratification of a treaty is not subjected to specific requirements other than a majority vote in Parliament. Overall, the Belgian Constitutional Court gives evidence of a strikingly Europe-friendly attitude, in line with attitudes at the political level and in society. Consequently, both the Europeanisation of constitutional rights and the implementation of international and EU law that potentially restrict fundamental rights, hardly trigger public debate. This approach, however, may change in the future. Surveys demonstrate that confidence in the European integration project is in decline amongst young adults. In 2016, after the submission
\end{abstract}

Patricia Popelier is Professor of Constitutional Law and Head of the Government and Law Research Group at the University of Antwerp. e-mail: patricia.popelier@uantwerpen.be.

Catherine Van de Heyning is Professor of Human Rights at the University of Antwerp. e-mail: catherine.vandeheyning@uantwerpen.be.

Patricia Popelier wrote Parts 1 and 3, and Sect. 2.5. Catherine Van de Heyning wrote Part 2. All websites accessed 3 November 2015. Text submitted 19 December 2014, with limited updates in November 2018.

P. Popelier $(\bowtie) \cdot$ C. Van de Heyning

University of Antwerp, Antwerp, Belgium

e-mail: patricia.popelier@uantwerpen.be

C. Van de Heyning

e-mail: catherine.vandeheyning@uantwerpen.be

(C) The Author(s) 2019

A. Albi and S. Bardutzky (eds.), National Constitutions in European

and Global Governance: Democracy, Rights, the Rule of Law,

https://doi.org/10.1007/978-94-6265-273-6_26 
of this paper, the Constitutional Court for the first time adhered to the constitutional identity doctrine, so far without further consequences. Also, it can be expected that the Constitutional Court would not easily accept external interference that would upset the delicate linguistic balances that are crucial for the stability of a divided Belgian State. Already, (Flemish) political parties are hesitant to join international treaties that they perceive as a threat to such balances.

Keywords The Constitution of Belgium - Constitutional amendments regarding EU and international co-operation - The Belgian Constitutional Court Europe-friendliness - 'Efficacy' approach • Constitutionalisation of the ECHR Europeanisation of constitutional rights - European Arrest Warrant Advocaten voor de Wereld, nullum crimen nulla poena sine lege/legality principle and access to the legally provided tribunal - Balancing of fundamental rights and market freedoms - Monism - Lack of public debate - Linguistic balances Constitutional review statistics - Absence of review of treaties - Constitutional challenge regarding independent regulatory agencies

\section{Constitutional Amendments Regarding EU Membership}

\subsection{Constitutional Culture}

1.1.1-1.1.2 Belgium was created in 1830, when the southern region separated from the United Kingdom of the Netherlands. Its Constitution, enacted in 1831, built on the Constitution of the United Kingdom of the Netherlands, the French Charte octroyée of 1830 and the French 1791 Constitution. Only 10 percent of the Belgian Constitution could be considered truly novel. ${ }^{1}$ Still, the Belgian Constitution was a model of liberal constitutionalism ${ }^{2}$ that influenced subsequent constitutions in Greece, Spain, Italy, the Netherlands, Luxembourg, Prussia and Romania. ${ }^{3}$

The Belgian Constitution was drafted as a pragmatic constitution, devoid of a preamble. Underlying principles such as national sovereignty, representative parliamentary democracy, the separation of powers and the rule of law were not explicitly mentioned, but were made concrete in provisions that enumerated fundamental rights and organised the legislative, executive and judicial powers. Initially, the Constitution relied on the elected Parliament and expressed its mistrust of the executive. While it empowered courts to not apply executive acts that are contrary to higher law, it introduced constitutional review of parliamentary acts only in 1980 through the establishment of a Constitutional Court (then 'Court of Arbitration' to stress its initially limited competences). By then, the Supreme Court

\footnotetext{
${ }^{1}$ Gilissen 1968, pp. 897-910.

${ }^{2}$ Popelier and Lemmens 2015.

${ }^{3}$ Gilissen 1968, p. 132; Alen 1984, pp. 897-910.
} 
had already broken the inviolability of Acts of Parliament by empowering courts to review such acts in the light of directly applicable international law. ${ }^{4}$

The Constitutional Court has gradually grown into a fully fledged human rights court that has constitutionalised the European Convention on Human Rights (ECHR) and relies heavily on the case law of the European Court of Human Rights (ECtHR). The Constitutional Court's power was initially limited to the competence to allocate rules between the federal state and the regional entities, but was widened in 1988 to include ensuring the equality clause and the clause protecting the rights and freedoms concerning education. While this situation lasted up to 2003 before Parliament conferred on the Court the right to directly review legislation for compatibility with fundamental rights and freedoms set out in the Constitution, this intervention only confirmed the powers that the Court had already assumed by linking the equality and non-discrimination clause with fundamental rights as protected by the Constitution or international treaties. The Court has now become an important actor in the constitutional field, providing individuals with an instrument to challenge Acts of Parliament which they consider as ignoring their interests. ${ }^{5}$ Although the Constitutional Court has in $21 \%$ of the cases found an Act of Parliament to violate the Constitution, ${ }^{6}$ Parliament has maintained confidence in the Constitutional Court. ${ }^{7}$

According to Art. 33 of the Constitution, all powers are derived from the 'Nation' as opposed to the 'People'. 8 The idea of national sovereignty was inspired by French constitutional theory, and implied a functional concept of the right to vote. Only in 1893 did the Constitution introduce universal (plural) voting. This was gradually widened, with equal suffrage for men introduced in 1918 and extended to women in 1948. Moreover, whereas the idea of a 'Nation' presupposes the notion of a single and undivided country, the Constitution now recognises that Belgium is a multinational federation. It enumerates four linguistic regions, divides the federal Parliament into two language groups and requires linguistic parity in the federal Government. While these two evolutions seem to have emptied the concept of national sovereignty, Art. 33 is still referred to as a constitutional obstacle for the organisation of nation-wide referendums. Meanwhile, the Constitution does allow for local advisory referendums and, since 2014, for advisory referendums organised by the subnational Regions.

\footnotetext{
${ }^{4}$ Cass. 27 May 1971, (1971) Pas. I, 886.

${ }^{5}$ Empirial research shows that participation in both anulment cases and preliminary references is largely dominated by private parties, especially individuals, followed by interest groups and firms. See De Jaegere 2017, pp. 100-111.

${ }^{6}$ De Jaegere 2017, p. 135.

${ }^{7}$ It should be taken into account that violations mostly concern minor points, referring to small parts of the Act, whereas more fundamental pleas are rejected.

${ }^{8}$ All translations of the Belgian Constitution are from the translation by the Legal Department of the Belgian House of Representatives, available at the website of the Constitutional Court, http:// www.const-court.be/en/basic_text/belgian_constitution.pdf.
} 


\subsection{The Amendment of the Constitution in Relation to the European Union}

1.2.1-1.2.3 The Belgian Constitution prescribes a rigid amendment procedure, which involves the enumeration of articles to be amended, the subsequent dissolution of Parliament and the revision of the enumerated articles by a two-thirds majority in both chambers of the newly elected Parliament.

This procedure has been used four times for reasons of EU membership. Three categories of amendments can be distinguished in this respect: (1) articles providing a constitutional basis for, or reinforcing the legitimacy of, the transfer of rights; ${ }^{9}$ (2) articles inserted in order to bring the Belgian legal system into conformity with EU obligations ${ }^{10}$ and (3) articles regulating domestic issues with regard to or by linking them to European elections. ${ }^{11}$ In what follows, they are listed in chronological order.

Article 34 was inserted in 1970 so as to retroactively provide for a legal basis for the accession of Belgium to supranational organisations in general. ${ }^{12}$ The Belgian Constitution does not include a specific 'Europe clause'. Article 34 of the Belgian Constitution stipulates in a general way that 'the exercising of specific powers can be assigned by a treaty or by a law to institutions of public international law'.

Secondly, in 1993, on the occasion of the fourth state reform that turned Belgium into a federal state, three amendments were linked to the European integration project. In this process, for the first time, the term 'supranational' appeared in the Constitution.

According to Art. 196 of the Constitution, the federal legislative and executive powers can legislate in place of the federated entities (Regions and Communities) 'in order to ensure the observance of international or supranational obligations'. The constituent power specifically had the infringement proceedings laid down in the EU treaties in mind. ${ }^{13}$ However, the provision does not give any indication as to how to distinguish 'international' from 'supranational' obligations. Also, the special majority law that implements Art. 169 does not provide for a different procedure for 'supranational' compared to 'international' obligations: in both cases, the federal authorities can only act as substitutes for a federated entity to comply with the judgment of an international or supranational court that has condemned the Belgian state for the non-observance of an international or supranational obligation committed by a Community or Region, on the condition that the federated entity was

\footnotetext{
9 Articles 34 and 168 Constitution.

${ }^{10}$ Articles 8 and 196 Constitution.

11 Articles 46, 117 and 168bis Constitution.

${ }^{12}$ By then, the Treaties establishing the European Steel and Coal Community, the European Economic Community and the European Atomic Energy Community had already been ratified. About the chronology of events, see Louis 1970, pp. 410-411 and Valticos 1984, pp. 13-15.

${ }^{13}$ Now Arts. 258 and 260 TFEU. See Parl. Doc., Senate, Extraordinary Session 1991-92, No. 457/1, 2-3.
} 
given a declaration of infringement and was involved in the entire procedure for the settlement of the dispute, including the procedure before the Court. In 2014, the special law was amended in order to simplify the substitution mechanisms in matters concerning the reduction of greenhouse gases in execution of the UN Framework Convention on Climate Change. In these matters, the federal authority can already act as a substitute if, for example, the European Commission declares an infringement in conformity with Art. 258 TFEU.

In 1993 as well, Art. 168 was inserted in the Belgian Constitution, granting the Houses the right to be informed of negotiations concerning any revision of the EU treaties. ${ }^{14}$ Article 168 gives evidence that the Constitution regards the EU treaties as special, as it leads to specific information obligations, whereas in the case of other treaties Parliament can only agree or disagree with the treaty after the negotiations have taken place. The constituent power aimed at giving greater legitimacy to the increasing transfer of powers to the European level. ${ }^{15}$ The Government promised to inform Parliament in a similar way regarding 'treaties of the same nature', which for example imply transfers of powers to similar supranational organisations, ${ }^{16}$ but this was never explicitly inserted in the Constitution. This promise has not gained much importance in practice. As an example of 'treaties of the same nature', the Government has referred to the Western European Union. ${ }^{17}$ This organisation, however, never carried much weight and was dissolved in 2011, with the EU having taken over its tasks.

Article 117, inserted in the course of the same fourth state reform, mentions the European Parliament, but only to secure a fixed legislative term for the parliaments of the federated entities, which, for the first time, were directly elected. According to this provision, community and regional parliamentary elections, as a rule, take place on the same day and coincide with European parliamentary elections.

A third phase occurred in 1998 when a provision was inserted in the Constitution in order to comply with the EU requirement, laid down in the Maastricht Treaty and EU directives, to give EU citizens the right to vote for municipality councils. As Art. 8 of the Constitution requires that a person have Belgian nationality for the exercise of core political rights such as the right to vote, the constitutionality of the ratification of the Maastricht Treaty was contested. ${ }^{18}$ In July 1998, the European Court of Justice (ECJ) established the failure to timely implement the EU directives regarding the right to vote and rejected the necessity to follow a rigid constitutional

\footnotetext{
${ }^{14}$ A similar obligation is inserted in Art. $16 \S 2$ Special Majority Law on the Reform of the Institutions, this time in favour of the federated parliaments, if the treaty touches upon their competences.

${ }^{15}$ Craenen 1993, p. 89 and Ingelaere 1994, p. 81.

${ }^{16}$ Parl. Doc. Senate 1991-1992, 100-16/2, 16; Parl. Doc. House 1992-1993, 797/3, 9.

${ }^{17}$ Parl. Doc. Senate 1991-1992, 100-16/2, 16.

${ }^{18}$ This was already a point of critique in the advisory report of 6 May 1992 of the Council of State, Legislation Division, on the law regarding the approval of the Maastricht Treaty, Parl. Doc. House of Representatives, Extraordinary Session 1991-1992, 48-482/1, 70-71.
} 
amendment procedure as a justification for non-compliance. ${ }^{19}$ The Constitution was revised in 1998 and implemented in $1999 .{ }^{20}$ The third paragraph added to Art. 8 of the Constitution now allows Parliament to establish the right to vote for EU citizens 'in accordance with Belgium's international and supranational obligations'. According to a fourth paragraph, this right can be extended to Belgian residents who are not citizens of an EU Member State. Hence, the Constitution allows Parliament to give a right to vote to non-Belgian citizens, whether EU citizens or not, but the extent of this right to vote depends upon EU law. In other words, the Constitution restricts the powers of Parliament, but refers to the EU to decide upon the substantive limits: the right to vote can only be given to residents in Belgium who are not Belgian citizens, in so far as EU law obliges Belgium to confer this right to EU citizens.

Finally, Art. 168bis was inserted in the Constitution in 2012, stating that a special majority law is to determine special rules regarding the election of the European Parliament, with a view to protecting the 'legitimate interests' of Frenchand Dutch-speaking people in the former province of Brabant. This article should be read against the background of Belgian multinational conflict management. When Brussels-Halle-Vilvoorde, Belgian's only electoral district across language borders, was split after decades of Flemish struggle, this provision ensured that francophone people in certain Flemish municipalities around the borders of Brussels could still vote for candidates on francophone electoral lists. The political parties wanted to insert this in the Constitution to secure it against actions before the Constitutional Court. ${ }^{21}$ As this article, along with other provisions required for the sixth Belgian state reform, was not mentioned in the list of constitutional articles that can be amended, a temporary provision was added to Art. 195 that lays down the amendment procedure. This provision allowed for constitutional amendment without prior dissolution of Parliament, but only to insert these articles and only during the one legislative session following the elections in 2010.

The same temporary provision enabled the amendment of Arts. 46 and 117, to provide that parliamentary elections at the federal level will also take place on the same day as the elections of the European Parliament, and that if the federal Parliament is dissolved before its term expires, the next term may not extend beyond the day when the election of the European Parliament following this dissolution is held. Article 46 of the Constitution, however, requires the adoption of a special majority law - and hence a new two-thirds majority and agreement in both language groups - for bringing the latter rule into force. At the same time, the regional parliaments may decide to choose another date for regional elections. Hence, the fixed five-year-term for the election of the European Parliament is now used to stabilise federal rather than regional legislatures.

\footnotetext{
${ }^{19}$ Case C-323/97 Commission v. Belgium [1998] ECR I-04281.

${ }^{20}$ Law of 27 January 1999, Official Gazette 30 January 1999.

${ }^{21}$ Parl. Doc. Senate 2011-2012, No. 5-1562/1, 2.
} 


\subsection{Conceptualising Sovereignty and the Limits to the Transfers of Powers}

1.3.1 Although Art. 33 of the Constitution states that 'all powers emanate from the Nation' and that these powers 'are exercised in the manner laid down by the Constitution', the sovereignty principle has never stood in the way of European integration. This was a project embraced by both the political and legal elites.

As mentioned in the previous section, Art. 34 of the Constitution provides for a constitutional basis for the transfer of powers to the European Union or other international or supranational organisations. A law adopted by an ordinary majority suffices to this effect. Until May 2014, the approval of both the House of Representatives and the Senate was required; since then, only the House of Representatives has this competence. No special procedural or substantive requirements apply apart from the obligation to inform Parliament. However, as EU treaties, as a rule, affect the federal and the federated entities, the approval of both the federal and the federated parliaments is required. ${ }^{22}$

1.3.2-1.3.3 Where the Constitution remains silent on the subject of the relations between domestic and international legal norms, the Belgian courts have filled this void. Already in 1971, the Cour de Cassation (hereinafter Supreme Court) pronounced its milestone Franco Suisse Le Ski judgment, which established the primacy of self-executing international law over national law. ${ }^{23}$ Although the case concerned EEC law and the judgment was a reply to the emerging ECJ case law pronouncing the primacy of EEC law, the Supreme Court gave primacy to all international law on the basis of a newly accepted monist theory. In the Orfinger case, the Conseil d'Etat, the Belgian Supreme Administrative Court (hereinafter Council of State) clarified that on the basis of Art. 34 of the Constitution, EU law also presides over the Constitution. ${ }^{24}$ Through this article, EU law, including ECJ case law, becomes part of the domestic legal order. In turn, the Supreme Court invoked the ECJ's Internationale Handelsgesellschaft judgment to recall that constitutional rights cannot call the validity of primary or secondary EU law into question. $^{25}$

The Constitutional Court also positions itself as a Europe-friendly court. It has no competence to directly review Acts of Parliament against the yardstick of international or supranational law, but does so indirectly, through the equality clause laid down in Arts. 10 and 11 of the Constitution, and by interpreting fundamental rights in conformity with similar treaty rights. It accepts the primacy of

\footnotetext{
22 Article 167, § 4 of the Constitution and Cooperation Agreement.

${ }^{23}$ Cass. 27 May 1971, (1971) Pas. I, 886.

${ }^{24}$ Council of State 5 November 1996, 62.922. This was confirmed in three other decisions of the same date: Goosse, Gerfa and De Baenst.

${ }^{25}$ Case C-11/70 Internationale Handelsgesellschaft [1970] ECR 01125; Cass. 2 June 2003, No. S020039N, www.juridat.be.
} 
international law over national legislation ${ }^{26}$ and readily refers preliminary questions to the ECJ concerning both interpretation and validity issues. ${ }^{27}$ In the period 2000 2014, the Constitutional Court referred to the ECHR in 32\% of its judgments, to EU law in $10 \%$ and to other international law in $18 \%$ of cases. ${ }^{28}$ Also, it quoted both ECJ and ECtHR case law in $9 \%$ and $14.3 \%$ of its judgments, respectively. ${ }^{29}$

On the other hand, the Constitutional Court has assumed the power to review parliamentary acts giving assent to treaties. ${ }^{30}$ In this way, it indirectly reviews the content of treaties against the Constitution. In the case of a violation, the parliamentary act cannot be applied, and the treaty is deprived of legal power within the domestic legal order. Although the Court had shown reluctance to also consider petitions challenging Acts providing for assent to an EC/EU treaty, ${ }^{31}$ Parliament has interfered to ensure the smooth implementation of EU law. As a result, the Constitutional Court no longer has jurisdiction to reply to preliminary references concerning an Act of assent to an EU Treaty or to the European Convention on Human Rights or its Protocols. ${ }^{32}$ Consequently, EU treaties cannot be challenged before the Constitutional Court through the Act providing for assent, except by way of an annulment request. In such case, however, specific time limits lessen the effectiveness of this option, as the request has to be lodged before the Court within 60 days after publication of the Act. Legal concerns regarding EU treaties can still be raised by the legislation division of the Council of State. The Government is obliged to ask the Council's independent expert advice, but is not bound by it.

Until now, the Constitutional Court has seemed to accept the supremacy of EU law over the Constitution without limitations. Although in doctrine its stance regarding secondary norms of EU law has been called ambiguous, ${ }^{33}$ the Court has refused to consider the validity of an EU directive or regulation, or the law implementing such act, if Parliament does not dispose of discretionary leeway. It has considered the unity of the European Union and has referred to the ECJ if the validity of an EU act has been at stake. ${ }^{34}$

What is noteworthy is the Care Insurance case, where the Constitutional Court invalidated a Flemish statute following a preliminary ruling of the ECJ even though this cut across the constitutional criteria for the distribution of powers between the

\footnotetext{
${ }^{26}$ It even regards itself explicitly as 'a guardian of EU law', see Const. Court No. 151/2003, 26 November 2003.

${ }^{27}$ It referred 24 preliminary questions to the ECJ in a period of 18 years (1997-2014). The frequency gradually increased, with four preliminary references in 2012 and in 2013.

${ }^{28}$ De Jaegere 2017, p. 186-190.

${ }^{29}$ Ibid.

${ }^{30}$ For the first time in Const. Court. No. 26/91, 16 October 1991.

${ }^{31}$ Const. Court No. 76/94, 18 October 1994 (annulment request).

${ }^{32}$ Article 26, § 1bis Special Majority Law on the Constitutional Court. The Constitutional Court applied this rule even before the provision came into force, Const. Court No. 3/2004, 14 January 2004.

${ }^{33}$ Cloots 2008, pp. 50-52.

${ }^{34}$ Const. Court No. 128/2009, 24 July 2009.
} 
Belgian federal level and the federated communities. ${ }^{35}$ However, the Constitutional Court, while claiming to fully abide by ECJ rulings, sometimes deviates in a silent or hidden way. In one case, the Constitutional Court ignored an ECJ ruling that restrictions of intra-Community trade require a specific analysis on the basis of scientific studies. ${ }^{36}$ In the Money Laundering case, the Constitutional Court explicitly stated that it followed the ECJ ruling, according to which the Directive did not violate Art. 6 ECHR, but it accepted the implementing law only in so far as it was given a broader interpretation than the one provided by the ECJ. ${ }^{37} \mathrm{~A}$ more explicit example is the Bressol case, in which the Constitutional Court openly disagreed with the ECJ on whether the financial implications of students from other Member States could justify measures restricting access to higher education on the basis of nationality. ${ }^{38}$

\subsection{Democratic Control}

1.4.1 Article 34 of the Constitution is a general enabling clause, which does not impose specific procedural requirements or substantive restrictions to a transfer of powers. A simple majority in Parliament suffices. If a treaty contains a provision that is contrary to the Constitution, ratification should be preceded by an amendment of the Constitution, which implies a renewal of Parliament and a two-thirds majority. In reality, however, this procedure is not followed and, as mentioned, Parliament has barred the possibility to refer a preliminary question to the Constitutional Court regarding the constitutionality of a parliamentary act giving assent to an EU Treaty or the ECHR.

Dual federalism, however, complicates the procedure. In Belgium, the federated entities ('Communities' and 'Regions') are treated as being at an equal level with the federal Government, and external relations are governed by the principle 'in foro interno, in foro externo'. As EU treaties are usually 'mixed treaties', comprising matters that in the national legal order belong to the field of competences of both the federal level and the federated entities, the approval of all federated parliaments is required. At the federal level, until May 2014, an ordinary majority in both the House of Representatives and the Senate was required. The Belgian constituent power did not seize the opportunity to transform the Senate into a more genuine chamber of the federated entities, to simplify the procedure and give federated parliaments the right

\footnotetext{
${ }^{35}$ Const. Court Nos. 33/2001, 13 March 2001 and 11/2009, 21 January 2009; Case C-212/06 Gouvernement de la Communauté française and Gouvernement wallon [2008] ECR I-01683. For a critical view regarding the ECJ's refusal to respect the institutional autonomy of federal Member States, see Verschueren 2011, pp. 211-223.

${ }^{36}$ Compare Case C-480/03 Clerens \& bvba Valkeniersgilde v. Walloon Government Order of 1 October 2004 (unpublished), with Const. Court No. 28/2005, 9 February 2005.

${ }^{37}$ Const. Court No. 10/2008, 23 January 2008. More on this case in Popelier 2012, p. 84.

${ }^{38}$ Const. Court No. 89/2011, 31 May 2011, B.4.4.-4.5.
} 
of approval only through the Senate. Instead, the constituent power unequivocally opted for a veto right for each subnational parliament, even the smallest amongst them, and denied the Senate the power to give approval to treaties. Theoretically, the Parliament of the German-Speaking Community could obstruct the coming into force of a European Treaty, even though, with 75,000 inhabitants, it represents less than $1 \%$ of the Belgian population. ${ }^{39}$

Despite the functioning of an advisory committee on European Affairs composed of members of the House of Representatives as well as Belgian members of the European Parliament, ${ }^{40}$ the involvement of Parliament in EU decision making is relatively weak. This was demonstrated in a study comparing parliamentary control capacity, based upon the strength of special parliamentary committees on European affairs, access to information and voting instructions. ${ }^{41}$

As mentioned, Art. 168 of the Constitution contains specific information obligations in the case of negotiations on a revision of the EU treaties. The subsidiarity mechanism following from the subsidiarity protocol ${ }^{42}$ is not enshrined in the Constitution. However, prior to this protocol, a special majority law inserted the obligation to inform regarding all normative acts of the European Commission and gave the federal and federated parliaments a right to give advice. ${ }^{43}$

The federated parliaments are also involved in the subsidiarity procedure. The Belgian Declaration No. 51 holds that the term 'national parliaments' in the EU Treaties encompasses subnational parliaments in the Belgian legal order. ${ }^{44} \mathrm{~A}$ co-operation agreement was signed by the eight chairs of the legislative assemblies in 2005, which was revised in 2008, and then again in 2017 in light of the latest state reform and the transformation of the Senate. A conflict may arise, as the reformed Senate no longer has powers in international and EU affairs, ${ }^{45}$ whereas Art. 7 of the Protocol states that 'in the case of a bicameral Parliamentary system, each of the two chambers shall have one vote'. According to the co-operation agreement, each federated parliament can submit a reasoned statement, and votes are cast in such a way that federal and subnational opinions are positioned next to one another, without fostering institutional dialogue. ${ }^{46}$ The revised co-operation agreement does not differ in this respect.

1.4.2 The Belgian constitutional system does not allow for the organisation of nation-wide referendums. While the Constitution does not explicitly ban

\footnotetext{
${ }^{39}$ See Rimanque 2002, p. 76.

${ }^{40}$ Article 68 Rules of Regulation of the House of Representatives.

${ }^{41}$ Raunio 2005, p. 324.

42 Protocol (No. 2) on the Application of the Principles of Subsidiarity and Proportionality.

${ }^{43}$ Article 92quater Special Majority Law on the Reform of the Institutions.

${ }^{44}$ Declaration No. 51 of the Kingdom of Belgium on the national parliaments, 17.12.2008, $P B C$ 306, 287.

45 One exception concerns Acts of Parliament that implement supranational or international obligations if the federated entities have failed to do so, based on Art. 169 Constitution.

${ }^{46}$ Popelier and Vandenbruwaene 2011, p. 223.
} 
referendums, it is inferred from Art. 33, which refers to the 'Nation' as the source of all powers instead of the 'People', and which states that all powers are exercised in the manner laid down in the Constitution. Hence, referendums can only be held in so far as the Constitution allows for it. One nation-wide (advisory) referendum was held nevertheless, in 1950, concerning the position of King Leopold III after World War II. As this referendum aggravated the political crisis it was intended to resolve, nation-wide referendums are not only considered unconstitutional, but they are also regarded as a threat to the delicate balance between the two major language groups which constitute the divided Belgian state. The reason is that the outcome of a referendum may clearly demonstrate the cleavage between the Flemings and francophone people, while lacking the instruments to mitigate the differences. ${ }^{47}$

The Constitution does explicitly allow for local advisory referendums and, since the recent sixth state reform, gives the right to organise advisory referendums to the federated Regions within their exclusive spheres of competence. ${ }^{48}$ As EU treaties are mixed treaties, regional referendums regarding the approval of these treaties are excluded. Regularly, proposals are submitted in the federal Parliament aimed at enabling or requiring the organisation of referendums regarding the approval of (EU) treaties in general, ${ }^{49}$ a particular EU treaty ${ }^{50}$ or the accession of a (possible) new Member State. ${ }^{51}$ These proposals are initiated by members of various Flemish as well as francophone political parties, from left-wing to right-wing. Nevertheless, they are hardly ever discussed.

\subsection{The Reasons for, and the Role of, EU Amendments}

1.5.1-1.5.2 Reasons for EU amendments Article 34, enabling the transfer of powers to international organisations, was inserted into the Constitution in 1970, in order to end ongoing debate on whether access to the European Communities was

\footnotetext{
${ }^{47}$ Popelier 2005, pp. $115-116$.

${ }^{48}$ Article 39bis Constitution.

49 Parl. Doc. House of Representatives 2010-2011, 53-999/1; 2007-2008, 52-794/1; 2007-2008, 52-332/1; 2004-2005, 51-1818/1; Senate 1995-1996, 1-295/1; 1995-1996, 1-293/1; 1995-1996, $1-161 / 1$.

${ }^{50}$ Treaty on Stability, Coordination and Governance: Parl. Doc. House of Representatives 20112012, 2105/1; Parl. Doc. Senate 2011-2012, 5-1613/1; Treaty of Lisbon: Parl. Doc. House of Representatives 2007-2008, 52-591/1; 2007-2008, 52-584/1; Treaty establishing a Constitution for Europe: Parl. Doc. House of Representatives 2003-2004, 51-317/1; 2003-2004, 51-297/1; 2003-2004, 51-281/1; 2003-2004, 51-1531/1; 1988-1989, 47-757/1; Senate 2003-2004, 3-950/1; 2003-2004, 3-282/1; 2003-2004, 3-250/1; Senate, 1988-1989, 595/1; Treaty of Amsterdam: Parl. Doc. House of Representatives 1997-1998, 1429/1; Parl. Doc. Senate 1997-1998, 2-889/1; Treaty of Maastricht: Parl. Doc. House of Representatives 1991-1992, 48-576/1; Parl. Doc. Senate 1991-1992, 1-440/1.

51 Turkey: Parl. Doc. Senate 2003-2004, 3-919/1; List of 12 countries: Parl. Doc. House of Representatives, 2000-2001, 50-1094/1; 1999-2000, 509/1.
} 
in conformity with the Constitution. Several constitutional experts were of the opinion that joining a supranational Europe violated Art. 33 of the Constitution, which states that all powers emanate from the Nation and are exercised in the manner laid down by the Constitution. ${ }^{52}$ Other experts, along with the legislative chambers, argued that Art. 33 only referred to domestic issues and did not prevent the transfer of powers to international organisations. ${ }^{53}$ The legislation division of the Council of State took a middle position, stating that the Constitution did not allow for the transfer of 'essential prerogatives' assigned to the national authorities. $^{54}$ The legislative assemblies, however, opted for a firm constitutional basis, considering the changing nature of modern international organisations. ${ }^{55}$

Legality concerns also explain the insertion of a provision in Art. 8 of the Constitution, enabling the right to vote for non-Belgian citizens of the European Union. The Council of State had, on several occasions since 1980, pointed out that a constitutional amendment was required if non-Belgian residents were to be granted the right to vote for municipality councils. ${ }^{56}$ Hence, unsurprisingly, the Council of State considered the law giving approval to the Treaty of Maastricht unconstitutional, as this Treaty introduced the right of every citizen of the Union residing in a Member State of which he is not a national, to vote and to stand as a candidate in municipal elections. ${ }^{57}$ Parliament approved the treaty nevertheless, relying on the Government's argument that implementation of the treaty required the issuing of a directive. ${ }^{58}$ The Constitution was finally amended in December 1998 , four years after the issuing of the directive. ${ }^{59}$ The rigid procedure for constitutional amendments, requiring the renewal of Parliament, as well as disagreement regarding the extension of the right to vote to non-EU citizens residing in Belgium, explain this belated action.

\footnotetext{
${ }^{52}$ See in particular the opinion by Dor G., Ganshof van der Meersch W.J., De Visscher P. and Mast A., Parl. St. House of Representatives 1952-1953, 696.

${ }^{53}$ See also Rimanque and Wouters 1998, p. 10. Both positions were reflected in the Council of State's advice of 12 January 1953, Parl. Doc. House of Representatives 1952-1953, 163.

${ }^{54}$ Council of State, advice of 12 January 1953, Parl. Doc. House of Representatives 1952-1953, 163. For this reason, it considered that approval of the European Defence Community Treaty violated the Constitution, unless justified by an inescapable and urgent necessity. The same position was held in subsequent advice, but ignored by the political actors. For an overview, see Velaers 1999, p. 236.

${ }^{55}$ Commission Report, Parl. Doc. Senate 1969-1970, No. 275.

${ }^{56}$ Council of State, Advice of 22 October 1980, Parl. Doc. House of Representatives 1985-1986, 262/2, 3-10. For an overview, see Velaers 1999, p. 59.

${ }^{57}$ Advice of 6 May 1992, Parl. Doc. 1991-1992, 48-482/1.

58 Parl. Doc. House of Representatives, Special Session 1991-1992, 48-482/1, 90. The Council of State refuted these arguments: Advice of 6 May 1992, Parl. Doc. 1991-1992, 48-482/1, 71.

${ }^{59}$ Council Directive 94/80/EC of 19 December 1994 laying down detailed arrangements for the exercise of the right to vote and to stand as a candidate in municipal elections by citizens of the Union residing in a Member State of which they are not nationals, [1994] OJ L 368/38.
} 
1.5.3 The role of the Belgian Constitution in a multilevel environment Legal systems within the EU that are obliged to implement EU law in the domestic legal order are faced with the question of the extent to which limitations of power that follow from external sources can be accepted, while maintaining legitimacy within the legal order. Two main approaches can be discerned: an 'efficacy approach', which is predominantly occupied by the concern for efficient through-put of EU law, and a 'legitimacy approach', which is specifically concerned with providing legitimacy to inflowing EU law. ${ }^{60}$ If a legitimacy approach is adopted, ideally, (a) the transfer of powers is submitted to special procedural and/or substantive conditions, (b) the precedence of EU law over the constitution is contested and (c) constitutional or supreme courts play the role of watchdogs over the constitution, assuming the power to ultimately delineate competences. If an efficacy approach is adopted, (a) the transfer of powers to the EU is allowed without special formal conditions, (b) the precedence of EU law over national law, including the constitution, is uncontested and (c) the judicial review of EU laws and treaties is constrained.

In Belgium, an efficacy approach clearly dominates. First of all, Art. 34 of the Constitution that allows for the transfer of powers does not impose specific conditions other than a law adopted by a simple majority (a). The precedence of EU law over the Constitution is uncontested (b) and the courts, including the Constitutional Court, are Europe-friendly (c). This is in line with the general approach towards European integration that Belgium has taken from the outset, along with other small countries such as the Netherlands and Luxembourg, because national interests in terms of both the economy and international relations have coincided with EU interests. ${ }^{61}$ Of course, public sentiment towards the European Union evolves, in which case an efficacy approach may harm the perceived legitimacy of the European project. Until now, Belgian citizens have still been positive about the EU and its democratic functioning, when compared to other citizens of the EU. ${ }^{62}$ A recent survey nonetheless reveals that support for the European integration project is decreasing amongst young adults. ${ }^{63}$

The efficacy approach is somewhat undermined by the consequences of dual federalism, as every federated entity has to give assent to an EU treaty. The sixth state reform gave the opportunity for a more efficient procedure. As the Belgian Senate was transformed into a genuine chamber of the federated entities, it would have been sensible to simplify the procedure and give the federated entities the right of approval only through the Senate. In that case, the federated entities would have been denied a veto right, but they would still have been able to discuss a treaty

\footnotetext{
${ }^{60}$ Popelier 2014a, pp. 300-319.

${ }^{61}$ Bribosia 1998, p. 32.

${ }^{6}$ See the Belgian report for the Standard Eurobarometer 80, L'opinion publique dans l'Union européenne - Rapport National Belgique, fall 2013, http://ec.europa.eu/public_opinion/archives/ eb/eb80/eb80_be_fr_nat.pdf.

${ }^{63}$ Elchardus and Te Braak 2014.
} 
jointly, and veto the treaty under ordinary or specific majority requirements. By contrast, the Belgian constituent power opted for a more confederal approach and maintained the federated entities' veto rights, while depriving the Senate of its right of approval. ${ }^{64}$

\section{Constitutional Rights, the Rule of Law and EU Law}

\subsection{Fundamental Rights and General Principles of Law in the Belgian Constitution}

2.1.1 The Belgian Constitution clusters the constitutional rights and freedoms in Title II Constitution titled 'on Belgians and their rights'. ${ }^{65}$ This chapter is quite extensive as to the number and nature of constitutional rights entrenched therein, including the rights of the child and several social and economic rights (the right to education, work, housing). Certain classic fundamental rights included in the Constitution provide broader protection than analogous rights entrenched in international or regional treaties, e.g. prohibition of the imposition of pre-emptive measures which may hinder the enjoyment of specific rights and freedoms such as the right to enter into associations. ${ }^{66}$

The Constitution provides for a number of general principles of law without, however, formally distinguishing between principles and rights. For example, the Constitution provides for the prohibition of retroactive legislation or punishment, or the legality principle (nulla poena sine lege) (Arts. 12 and 14 Constitution). Other general principles, such as the proportionality principle, legal certainty and legitimate expectations have not been entrenched in the Constitution.

Constitutional rights are enforceable in courts. First, the Constitutional Court provides centralised constitutionality review, by examining the compatibility of legislation with the constitutional rights entrenched in Chapter II of the Constitution and a given number of other constitutional rights. If the Court finds legislation to be incompatible, it annuls the legislation. Secondly, ordinary courts and administrative courts provide decentralised review. If they find secondary legislation to violate the Constitution or statutes to violate international treaties, they can disapply (not annul) the provisions in question or provide a constitutionally conforming interpretation of the legislation. The Act on the Constitutional Court regulates the interaction between the ordinary or administrative courts and the Constitutional

\footnotetext{
${ }^{64}$ On the Belgian confederal approach, compared to the UK centralist and the German federal approach, see Popelier 2014b, p. 17.

${ }^{65}$ A limited number of fundamental rights have been entrenched in other chapters, including rights concerning fairness in taxation (Arts. 170-171).

${ }^{66}$ Article 27 Constitution.
} 
Court. ${ }^{67}$ This Act provides for the rules applicable when these courts are obliged to make a reference to the Constitutional Court by means of a preliminary reference procedure.

2.1.2 There is no general limitation clause in the Belgian Constitution. Some specific provisions establishing constitutional rights provide for limitation clauses. The general approach to these limitations is that, in line with the rule of law, limitations to constitutional rights can only be provided by law. ${ }^{68}$ For example, the Belgian Constitution provides for a limitation to the right of peaceful assembly, namely that it must be in accordance with the law. ${ }^{69}$ As such, Parliament is given a wide discretion to regulate the conditions and criteria for peaceful assembly.

However, such limitations are not without restriction. First, in principle, preventive measures to the exercise of constitutional rights and freedoms are prohibited ${ }^{70}$ in order to ensure the broadest protection of personal freedom. ${ }^{71}$

For example, while Parliament may limit the right of peaceful assembly, it may not submit peaceful assembly to prior authorisation. ${ }^{72}$ In addition, certain material limitations have been entrenched in specific provisions. For example, the Belgian Constitution provides that no one can be deprived of his or her property except in the case of expropriation for a public purpose, in the cases established by law and in return for fair compensation remunerated beforehand. ${ }^{73}$

2.1.3 The Belgian concept of the rule of law, influenced by the classic French notion as developed during the Enlightenment, focuses on protection against arbitrary power. This notion is articulated in formal as well as in material requirements to the exercise of power by government. The Belgian conception of the rule of law (état de droit) is currently understood as protection against the arbitrary use of power by public authorities by requiring that public power be exercised in line with the existing and applicable legal norms. ${ }^{74}$

There is no separate category in the Constitution regarding the rule of law, nor a specific title. However, it is without any doubt that the Belgian polity and Constitution are based on this notion. First, the main principles of the formal concept of the rule of law are explicitly entrenched in the Constitution, in particular the separation of powers (Title III, Title IV, Title V). Secondly, the underpinning

\footnotetext{
${ }^{67}$ Special Act of 6 January 1989 on the Constitutional Court, Official Gazette 7 January 1989.

${ }^{68}$ Van Delanotte considers this an example of the immense trust the 19th century constitutionalists put in Parliament. Vande Lanotte and Goedertier 2010, p. 281.

${ }^{69}$ Article 26 Belgian Constitution.

${ }^{70}$ This notion is mentioned explicitly in Arts. 19, 24, 25, 26 and 27 of the Constitution. However, jurisprudence accepts that this prohibition is of general nature and applies in principle to all constitutional rights and freedoms. Wigny 1952, pp. 267-269 and Alen 1995, p. 499.

${ }^{71}$ Wigny 1952, p. 269.

72 The only exception provided are gatherings in public space.

${ }^{73}$ Article 16 Belgian Constitution.

${ }^{74}$ Popelier 1997, p. 97; Dujardin et al. 2014, p. 367; Mast and Dujardin 1985, p. 23; Allen 1995, p. 12.
} 
material criteria of this principle are also entrenched as specific rights in the Constitution, such as the equality of all persons before the law (Art. 10), the application of the law without discrimination (Art. 11) and the legality principle with regard to punishments (Art. 14).

Protection of the rule of law has been invoked before the Constitutional Court as a general principle of law of constitutional nature and, thus, the Constitutional Court has been asked to protect given rights read in the light of this general principle. ${ }^{75}$

In several cases the Constitutional Court has reiterated that Belgium is governed by the rule of law and that such conclusion follows from the Constitution itself. The Constitutional Court has held that the Belgian polity is conceived as a state under the rule of law. ${ }^{76}$ Consequently, the Constitutional Court has protected several legal principles and rights on the basis of protection of this notion, such as the legality principle and equality principle. In particular, the Constitutional Court has stated explicitly in several judgments that protection of the rule of law implies that public authorities are subjected to the law and, thus, government is to exercise power in line with the applicable legal norms. ${ }^{77}$ The Constitutional Court additionally protects the material requirements of the rule of law, in particular the protection of constitutional rights and freedoms. The Court has held that protection of the rights of defence and the right to a fair trial ensue from protection of the rule of law by the Belgian legal order. ${ }^{78}$

\subsection{The Balancing of Fundamental Rights with Economic Free Movement Rights}

2.2.1 Historic reasons explain the absence of systemic conflicts between the protection of fundamental rights and economic free movement rights in Belgium. For over 150 years, the Belgian Constitution played only a marginal role in Belgian case law, given that courts were not allowed to review legislation for compatibility with the Constitution. ${ }^{79}$ While courts could provide for a constitutionally conforming interpretation, ${ }^{80}$ the absence of constitutional review restricted the development of a true constitutional jurisprudential culture.

\footnotetext{
${ }^{75}$ E.g. Const. Court No. 41/201115, March 2011.

${ }^{76}$ Const. Court No. 151/200215, October 2002, para. B.3.2.

77 Const. Court No. 151/2002, 15 October 2002, para. B.3.2.

${ }^{78}$ Const. Court No. 98/2008, 3 July 2008, para. B.7; Const. Court No. 77/2012, 14 June 2012, B.3.1.

${ }^{79}$ The inviolability of legislation was not explicitly provided in the Belgian Constitution or other legislation. However, in a judgment of 1849 the Supreme Court held that courts were not competent to review the constitutionality of legislation. Cass. 23 July 1849, Pas. 1849.

${ }^{80}$ The Supreme Court held that if several interpretations of legislation were possible, courts were to select the interpretation that conformed to the Constitution. Cass. 20 April 1950, Arr. Verbr. 1950.
} 
Belgian courts were in contrast exposed to the law of the European Community and later of the European Union early on. Belgium was a founding father of the EC and, therefore, the economic free movement rights as developed by the European Community were adopted in the Belgian legal sphere well before the development of constitutional review. In consequence, courts have in general been lenient towards accommodating economic free movement rights, in particular the free movement of goods. Already in 1971, the Court of Cassation proclaimed that domestic law should be set aside when incompatible with directly applicable international law provisions, including European Economic Community rules. ${ }^{81}$ As a result, Belgian courts have interpreted domestic norms in line with EU law and, if such coherent interpretation has not been possible, have set aside these norms.

A jurisprudential discussion on the constitutional limits of the precedence of these economic free movement rights of EU pedigree is thus recent. Two evolutions in Belgian constitutional history have put the automatic acceptance of the primacy of EU law over domestic norms into question. First, the development of constitutional review by the establishment of the Constitutional Court awakened a constitutional consciousness within Belgian academic, judicial and political circles. ${ }^{82}$

Secondly, during the last three decennia Belgium has swiftly transformed from a unitary state to a federal state whereby competences are divided between the federal state and the federated Communities and Regions. ${ }^{83}$ The equilibriums between the federal state and the Regions and Communities are key to the functioning of the Belgian state and have been entrenched in the Constitution or in legislation of constitutional nature. Consequently, certain EU rules and ECJ jurisprudence touching upon these balances have sparked debate on the limits of the unconditional acceptance of the primacy of EU law. ${ }^{84}$

Nevertheless, the interaction between the protection of constitutional rights and economic free movement rights is in general not considered as problematic. The Constitutional Court has adopted a pragmatic approach: if a conflict occurs between constitutional rights and economic free movement rights, the Court will engage in the discussion by sending preliminary questions to the ECJ requesting a decision on

81 Cass. 27 may 1971, Arr. Cass. 1971, 959.

${ }^{82}$ As was explained in Sect. 1.1, the Belgian Constitutional Court was established in 1980 in order to guard the division of competences between the federal state and the regional entities. The competences of the Court were extended over the course of two decennia providing the Court with the competence to review legislation on its compatibility with the constitutional rights and freedoms entrenched in Title II of the Constitution. Finally, the original name of the Court, "the Arbitrage Court', was replaced by 'Belgian Constitutional Court', in recognition of the evolution of the court from an arbiter between the federal state and regional entities to a fully fledged modern constitutional court.

${ }^{83}$ Supra Sects. 1.1 and 1.4.

${ }^{84}$ Such federal equilibrium was at stake in the only case where the Constitutional Court explicitly voiced critique on an ECJ judgment. See Const. Court No. 89/2011, 31 May 2011. At the same time EU law has been relied upon to mediate conflicts at the national level, in particular in regard to questions concerning federal conflicts. See Popelier and Voermans 2015, p. 106. More on this issue, see infra Sect. 2.8.1. 
the compatibility between the free movement rights and EU fundamental rights. Thus, the potential conflict between a given right and an economic free movement right is not framed as a conflict between a constitutional right and a free movement right, but as a conflict between a (EU) fundamental right and a free movement right. As a result, the Constitutional Court avoids open conflicts between EU law and constitutional law. However, in the literature, certain scholars state that there are constitutional limits to the application of EU law in the Belgian legal order, ${ }^{85}$ for example as regards the balancing of market freedoms and the right to strike or protest (see Sect. 2.6).

\subsection{Constitutional Rights, the European Arrest Warrant and EU Criminal Law}

\subsection{1-2.3.5 The reception and enforcement of the European Arrest Warrant}

The implementation of the EAW in Belgian law and its application The European Arrest Warrant (EAW) was implemented in Belgium in 2003. ${ }^{86}$ The Belgian Parliament copied the European Arrest Warrant Framework Decision (EAW Framework Decision) almost literally in the implementing act. ${ }^{87}$ The EAW implied essential changes to the Belgian legislation concerning extradition that was applicable before the introduction of the EAW. ${ }^{88}$ First, the Belgian law entrenched the principle of double criminality. A person could only be extradited if the offence for which extradition was requested was also accepted as an offence under Belgian law and was punishable in Belgium and in the requesting state by a prison sentence exceeding one year. The EAW meant that certain exceptions to this principle of double criminality had to be accepted. Secondly, the Belgian law provided that Belgian judges could refuse extradition if the person to be extradited held Belgian nationality. The EAW does not allow for such exception.

Some specifications were, however, introduced, in particular with regard to crimes for which the requirement of double criminality will continue to apply. ${ }^{89}$ The Belgian law stipulates explicitly that abortion and euthanasia will not be considered manslaughter under the list of crimes for which the criterion of double criminality of the offence in the requesting state and Belgium are no longer required.

\footnotetext{
${ }^{85}$ Maintaining that the Constitutional Court considers the Constitution supreme Craig 2004, p. 37; Bribosia 1998, pp. 21-22; Bombois 2004, pp. 143-150. Highlighting that the Constitutional Court has not embraced such vision explicitly Popelier 2008, p. 48 and Beirlaen 1992, p. 150.

${ }^{86}$ Act of 19 December 2003 concerning the European Arrest Warrant, Official Gazette 22 December 2003 (EAW implementing act).

${ }^{87}$ Council Framework Decision of 13 June 2002 on the European arrest warrant and the surrender procedures between Member States (2002/584/JHA), [2002] OJ L 190/1.

${ }^{88}$ Act of 15 March 1874, Official Gazette 17 March 1874.

${ }^{89}$ Article 5 EAW implementing act, supra n. 86.
} 
The EAW and constitutional challenges Given the essential changes imposed by the EAW on the Belgian system of extradition, it came as no surprise that the EAW, through implementation in Belgium, was tested before the Constitutional Court.

The first decision of the Constitutional Court on the EAW resulted from a procedure initiated by the NGO Advocaten voor de Wereld.$^{90}$ The NGO advocated that the absence of the double criminality (legality principle) requirement for extradition on the basis of an EAW violated the prohibition on discrimination and the right to equal treatment as stipulated in Arts. 10 and 11 of the Constitution. The Constitutional Court referred the question to the ECJ for a preliminary ruling, arguing that the absence of the double criminality principle in the implementing act followed directly from the EAW Framework Decision and, consequently, the question before the Constitutional Court raised an important point on the compatibility between the EAW Framework Decision and fundamental rights. ${ }^{91}$

In its 2007 judgment Advocaten voor de Wereld the ECJ decided on the preliminary questions referred by the Belgian Constitutional Court regarding the compatibility of the EAW Framework Decision and the legality and equality principles. ${ }^{92}$ The ECJ accepted that the Framework Decision was to respect fundamental rights, in particular those guaranteed in the ECHR and as they result from the constitutional provisions common to the Member States. For this reason, the Framework Decision should indeed respect the principle of the legality of criminal offences and penalties and the principle of equality and non-discrimination. ${ }^{93}$ However, the ECJ decided that the Framework Decision complied with those principles.

As regards the legality principle, the ECJ held that this principle does not require the double criminality of offences, but only that legislation must clearly define offences and the penalties they attract. ${ }^{94}$ The ECJ repeatedly emphasised that the Framework Decision by no means intended to harmonise the definition of offences among the Member States, but only to improve mutual co-operation in the field of extradition for the most serious crimes. It was not the intention of the Framework Decision to provide for the definition of offences and penalties, but merely to set the minimum criteria for those offences with regard to which the EAW applies. The Court found the Framework Decision to comply with this principle given that it only provides for extradition for those offences which are punishable in the issuing Member State 'as they are defined by the law of the issuing Member State'. ${ }^{95}$

\footnotetext{
${ }^{90}$ Const. Court No. 124/2005, 13 July 2005.

${ }^{91}$ Both at the level of the Constitutional Court and the ECJ more technical judicial questions were raised concerning the competence to enact the Framework Decision and implementing act. However, for the purpose of this contribution, the focus has been put on the fundamental rights issues concerned.

92 Case C-303/05 Advocaten voor de Wereld [2007] ECR I-03633.

${ }^{93}$ Ibid., paras. 45-46.

${ }^{94}$ Ibid., para. 50.

${ }^{95}$ Framework Decision, supra n. 87, Art. 2(2).
} 
The ECJ argued that the Framework Decision therefore only provides for extradition if the issuing state complies with the legality principle. ${ }^{96}$

As for the equality principle, the ECJ held that the choice of the 32 categories of offences for which the double criminality principle does not apply was objectively justified on the basis of several features, including the seriousness of the offences in adversely affecting public order and safety. ${ }^{97}$

Upon the return of the preliminary judgment of the ECJ, the Constitutional Court reverted extensively to the ECJ judgment, blending the reasoning of the ECJ with other arguments based on the preparatory works of the implementing act. ${ }^{98}$ The Constitutional Court emphasised that the absence of the double criminality principle for certain categories of offences did not imply that there is no judicial control by the judicial authorities. The Court stated that the double criminality principle was replaced by other criteria. ${ }^{99}$ The Court in particular referred to the criteria in the implementing act which define the cases in which the domestic authorities are even obliged to refuse extradition, such as compliance with the non bis in idem principle or age restrictions. ${ }^{100}$ It held that in view of the above, there was no violation of the legality and equality principles. ${ }^{101}$ This judgment is a typical example of the approach of the Constitutional Court vis-à-vis ECJ judgments: the Court will extensively refer to the ECJ judgment, but will add its own reasoning based on its previous case law and parliamentary works, blending the EU contentieux with the domestic constitutional contentieux.

The implementing act was tested for a second time before the Constitutional Court in 2009. ${ }^{102}$ This case originated from a preliminary reference by an investigation court. The referring court questioned whether Art. 8 of the implementing

\footnotetext{
96 Case C-303/05 Advocaten voor de Wereld, n. 92, paras. 52-53.

97 Ibid., paras. 57-58.

98 Const. Court No. 128/2007, 10 October 2007.

99 Ibid., paras. B.17.1-B.17.2.

100 Ibid., para. B.19.
}

${ }^{101}$ In its reasoning the Constitutional Court considered the compatibility of the implementing act with the constitutional rights from the perspective of Art. 6 ECHR. However, in its original request, the NGO questioned the compatibility of the prohibition of the constitutional equality principles in the light of Art. $6 \mathrm{ECHR}$, but also the constitutional right to have access to the legally provided tribunal (Art. 13 Constitution) and the right to liberty (Art. 12 Constitution). In the reasoning of the Constitutional Court, these articles play no role and no distinct reasoning is provided on the basis of these provisions. More in general, the case law of the Constitutional Court on procedural rights is almost entirely developed on the basis of Art. 6 ECHR and not on the basis of Art. 13 of the Constitution. The same is true with regard to Art. 5 ECHR and Art. 12 of the Constitution.

102 Const. Court No. 128/2009, 24 July 2009. In contrast to the Advocaten case, this judgment did not follow an application for annulment by an NGO, but originated from a preliminary reference from an investigation court, i.e. a court that decides at the end of a criminal investigation whether the case will be referred to a court which can decide on the merits of the case. In this case, the referring court limited the preliminary reference to a question on the compatibility of the implementing act with the right to equality (Arts. 10 and 11 Constitution). 
act violated the prohibition on discrimination and the right to equal treatment as stipulated in Arts. 10 and 11 of the Constitution. Article 8 of the implementing act provides that a judge cannot refuse the extradition of a person because the foreign judgment on the basis of which the European arrest warrant was delivered resulted from a trial in absentia. ${ }^{103}$ The Constitutional Court decided again that the provisions of the implementing act followed directly from the European Framework Decision and for that reason referred the question to the ECJ.

In contrast to the Melloni case, the preliminary question by the Constitutional Court did not question the compatibility of extradition in the case of an in absentia trial as such. ${ }^{104}$ The Belgian Constitutional Court merely asked whether extradition, in the case of an in absentia trial where the person concerned would have the opportunity in the requesting state to apply for a retrial, could be rendered conditional upon the return of the extradited person for the execution of the sentence. The ECJ in its judgment did not consider the case from a fundamental rights perspective. ${ }^{105}$ The ECJ decided that the Framework Decision was to be interpreted in such manner as to allow for judicial authorities to render the extradition of a person conditional upon his or her return to the executing state to serve the sentence, if the sentence was imposed in absentia. ${ }^{106}$

The Constitutional Court relied on the ECJ judgment when deciding the case, holding that the implementing act was to be interpreted so that judicial authorities could render the extradition conditional upon the return of the person extradited to serve the sentence if this person was convicted in absentia. ${ }^{107}$ The Constitutional Court did, however, refer to applicable fundamental rights criteria, in particular the right to a fair trial and ECtHR case law, in deciding that the provision would not be compatible with the right to equal treatment unless it were interpreted as rendering the extradition conditional upon the return of the person to Belgium to serve the sentence in the case of an in absentia trial. ${ }^{108}$ Again, the Constitutional Court closely followed the ECJ judgment but added its own reasoning.

\subsubsection{Other Relevant Issues in Fundamental Rights and Criminal Law}

The Belgian constitutional case law regarding criminal procedure clearly shows the dual impact EU law can have on fundamental rights protection: under certain circumstances EU law might limit the guarantees in domestic constitutional law while

\footnotetext{
103 Const. Court No. 28/2011, 24 February 2011.

${ }^{104}$ Case C-306/09 I.B. [2010] ECR I-10341. For a discussion on in absentia trials, see the preliminary reference question from the Spanish Constitutional Court in Case C-399/11 Melloni [2013] ECLI:EU:C:2013:107.

105 There was no reference in the judgment to fundamental rights nor a wider discussion on the compatibility of extradition in cases involving in absentia trial and fundamental rights.

${ }^{106}$ Case C-306/09 I.B., supra n. 104, para. 61.

${ }^{107}$ Const. Court No. 28/2011, 24 February 2011, para. B.2.7.

${ }^{108}$ Ibid., para. B.5.
} 
on other occasions EU law might actually improve the standards of protection. The Money Laundering Directive is an example of such limitation, while the so-called Salduz-Directive exemplifies the potential for upgrading standards of protection.

The implementation of the Money Laundering Directive ${ }^{109}$ in Belgian law was highly contested due to the obligation for independent legal professionals, including lawyers, to report information in a listed number of circumstances. This clearly implied a limitation of the professional secrecy of lawyers. The protection of professional secrecy of lawyers is not explicitly set out in the Belgian Constitution. However, it is considered in Belgium as an elementary condition for ensuring the right to an equal and fair trial as protected under Art. 6 ECHR as well as the lawyer-client privilege as protected under Art. 8 ECHR. Therefore, the Belgian Bars asked the Constitutional Court to annul the domestic act implementing the Directive. ${ }^{110}$ The Constitutional Court referred a preliminary question to the ECJ asking whether the obligation for professionals in the financial sector to report potential money laundering by clients to official authorities, as introduced by the Directive, violated the constitutional prohibition of discrimination read in the light of Art. 6 ECHR. ${ }^{111}$ Given that the Belgian implementing act almost entirely copied the text of the Directive, a finding by the Constitutional Court that the implementing act violates fundamental rights would imply that the Money Laundering Directive suffered the same flaws.

In its judgment Ordre des barreaux francophones et germanophone, the ECJ answered that the Directive establishing this obligation did not violate the constitutional right to non-discrimination read in the light of Art. 6 ECHR. ${ }^{112}$ The ECJ indicated that sufficient guarantees had been provided in the Directive, given that the obligation to report is limited to the execution of certain transactions, essentially those of a financial nature or concerning real estate, and no obligation to report was provided where a lawyer is called upon to assist or represent a client before the courts. $^{113}$

When the Constitutional Court was to decide the case after the ECJ judgment, it referred to the ECJ judgment, stating that the judgment had found that there was no violation of Art. 6 ECHR. ${ }^{114}$ However, the Constitutional Court proceeded to

\footnotetext{
${ }^{109}$ Directive 91/308/EEC of 10 June 1991 on prevention of the use of the financial system for the purpose of money laundering, [1991] OJ L 166/77 as amended by Directive 2001/97/EC of 4 December 2001, [2001] OJ L 344/76. The directive was implemented by the Act of 12 January 2004 amending the Act of 11 January 1993 relating to the prevention of the use of the financial system for the purpose of money laundering, Official Gazette 23 January 2004.

${ }^{110}$ Given the federal structure of Belgium, the Bar of Lawyers is divided into a Dutch-speaking section, a French- and German-speaking section, and a Dutch-speaking section and French-speaking section in Brussels.

${ }^{111}$ Const. Court No. 126/2005, 13 July 2005.

112 Case C-305/05 Ordre des barreaux francophones et germanophone and others [2007] ECR I-05305.

113 Ibid., paras. 33-35.

${ }^{114}$ Const. Court No. 10/2008, 23 January 2008, para. B.5.2.
} 
review whether the implementing act was compatible with Arts. 6 and 8 ECHR. The Constitutional Court had limited its preliminary question to the ECJ to the aspect of procedural rights, i.e. the compatibility with Art. 6 ECHR. It could therefore not rely on the ECJ judgment upon reviewing the compatibility with Art. 8 ECHR. The Court held that the implementing act did not violate the Constitution read in the light of Arts. 6 and 8 ECHR in so far as the act was interpreted as exempting lawyers from reporting information in the exercise of the essential activities of their profession. ${ }^{115}$ It maintained that this also applies to transactions listed in the Directive for which the reporting obligation is provided. It is unclear whether the refusal of the Constitutional Court to send another preliminary reference on compatibility with Art. 8 ECHR implied that the Court meant to emphasise its own authority to deal with such issues or, alternatively, whether the refusal was just a matter of pragmatics to ensure that the case would be decided within due time. $^{116}$

The introduction of the so-called Salduz-Directive, ${ }^{117}$ in contrast, will result in a better standard of protection of fundamental rights in comparison to the current standard held by the Constitutional Court. This Directive provides for the right to the assistance of a lawyer during an interrogation by police and judicial authorities. The Belgian provisions regulating consultation and assistance rights prior and during interrogations limit the assistance of a lawyer during an interrogation to persons deprived of liberty. ${ }^{118}$ The Belgian Constitutional Court based its reasoning on the ECtHR jurisprudence to find that the limitation to persons in custody did not violate Art. 6 ECHR. ${ }^{119}$ The implementation of the Directive implied the extension of this right to all persons who are interrogated and thus improve the standard of protection of procedural rights currently held by the Constitutional Court to be compatible with Art. 6 ECHR.

The Total Belgium case of the Constitutional Court is a second example where a reference to EU law has had a positive effect on the protection of fundamental rights in criminal proceedings. ${ }^{120}$ This case concerned the compatibility of the sanctions provided in Belgian law for evasion of taxes on mineral oils with the prohibition of disproportionate sanctions. The Act in question seriously limited the discretion of

\footnotetext{
115 Ibid., para. B.9.6.

${ }^{116}$ However, in subsequent cases no similar approach was taken, suggesting that this judgment should not be regarded as a principled stance of defiance towards the ECJ case law.

117 Directive 2013/48/EU of the European Parliament and the Council of 22 October 2013 on the right of access to a lawyer in criminal proceedings and in European arrest warrant proceedings, and on the right to have a third party informed upon deprivation of liberty and to communicate with third persons and with consular authorities while deprived of liberty, [2013] OJ L 294/1.

118 Act of 13 August 2011 amending the Code of Criminal Procedure and the Act of 20 July 1990 on temporary custody, Official Gazette 5 September 2011, 56347. These provisions were introduced following the ECtHR Salduz jurisprudence Salduz v. Turkey [GC], no. 36391/02, ECHR 2008.

119 Const. Court No. 07/2013, 14 February 2013, paras. B.9.1.-B.9.2.

${ }^{120}$ Const. Court No. 81/2007, 7 June 2007.
} 
judges to amend the fines provided in the Act, e.g. the judge could not adapt the fines mentioned to the circumstances of the case and take mitigating circumstances into account. ${ }^{121}$ Given that this Act implemented EU measures, the Constitutional Court relied on ECJ case law and found that the sanctions were to be effective but not disproportionate. The Constitutional Court in particular referred to the applicable article in the EU Charter of Fundamental Rights, even though the Charter was not yet in force at the time of the judgment. ${ }^{122}$

\subsection{The Data Retention Directive and the Belgian Constitutional Order}

2.4.1 The annulment procedure regarding the implementation of the Data Retention Directive 2006/24/CE ${ }^{123}$ was still pending before the Constitutional Court at the time of the ECJ's judgment in the Digital Rights Ireland case. ${ }^{124}$ The Directive had only been implemented on 30 July $2013^{125}$ and, hence, the annulment procedure had been initiated only shortly before the ECJ's judgment. ${ }^{126}$

The reason for this delay in implementation is of a less principled nature than was the case in Sweden. Belgium is in general slow in implementing directives and has already been penalised on numerous accounts by the European Commission for a lack of efficient and timely implementation. In reaction to threats by the European Commission to penalise Belgium for non-implementation of the Data Retention Directive, the Government speeded up the implementation of the Directive in the summer of July 2013. For this reason, the Government left only little time for debate or interventions by experts during the implementation by Parliament.

The former Belgian Deputy Prime Minister and public law professor Vande Lanotte had suggested that the judgment of the ECJ must not have consequences for the Belgian act, given that more guarantees for fundamental rights were entrenched in the implementing act. ${ }^{127}$ This position was not followed by the Constitutional

\footnotetext{
${ }^{121}$ Act of 22 October 1997 concerning the structure and the tariffs of taxes concerning mineral oil, Official Gazette 20 November 1997.

${ }^{122}$ Const. Court No. 81/2007, 7 June 2007, para. B.9.2.

${ }^{123}$ Directive 2006/24/EC of the European Parliament and of the Council of 15 March 2006 on the retention of data generated or processed in connection with the provision of publicly available electronic communications services or of public communications networks and amending Directive 2002/58/EC, [2006] OJ L 105/54.

${ }^{124}$ Joined cases C-293/12 and C-595/12 Digital Rights Ireland [2014] ECLI:EU:C:2014:238.

125 Act of 30 July 2013 concerning the amendment of Articles 2, 126 and 145 of the Act of 13 June 2005 on the Electronic Communication and Article 90decies of the Code of Criminal Procedure, Official Gazette 28 August 2013, 56109.

126 The procedure had been initiated by the Belgian League of Human Rights and the Francophone and German Order of Lawyers on 24 February 2014.

${ }^{127}$ De Tijd 9 April 2014, available at www.detijd.be.
} 
Court. Given that the Belgian act is almost a literal copy of the European Directive, in particular with regard to the provisions criticised by the ECJ, the Constitutional Court found the implementing act to be in violation of the right of privacy as protected by the Constitution, read in the light of EU fundamental rights and the ECHR. It explicitly mentioned that the implementing act violated EU fundamental rights for the same reason as stated by the ECJ. ${ }^{128}$ Upon the annulment by the Constitutional Court, the Belgian legislator did not await a new European initiative but rather introduced a new Act in 2016. This Act still allowed for bulk retention of communication data but limited the access to such data for law enforcement. After the new ECJ judgment Tele2/Watson in which the ECJ found bulk retention of communication data to be in violation of the protection of personal data and privacy, it was expected that the Constitutional Court would once again strike down the Belgian Act. Instead, the Constitutional Court sent new preliminary questions to the ECJ implicitly criticising the Luxembourg case law by highlighting the importance of bulk retention for criminal investigations. The preliminary questions are a clear invitation for the ECJ to reconsider its position or at least provide some margin to the national courts. ${ }^{129}$

\subsection{Unpublished or Secret Legislation}

2.5.1 The question of secret legislation by EU institutions has not risen in Belgium. Most probably, it would not be considered as binding upon individuals. According to Art. 190 of the Constitution, laws are not binding upon third parties until publication 'in the manner described by the law'. This article is considered to articulate a more general principle of law according to which citizens can only be bound by laws if they have been properly published. ${ }^{130}$ The Belgian Constitutional Court interprets this article in the light of the rule of law, to require that authorities make substantial efforts to ensure equal access to the law for each person. ${ }^{131}$ The duty to publish includes annexes with normative content. ${ }^{132}$ Also, legislative acts that simply refer to provisions in an EU directive do not comply with Art. 190 of the Constitution, if the directive has not been published in the Belgian Official Gazette. ${ }^{133}$ While unpublished law cannot have any effect on third parties, it

\footnotetext{
${ }^{128}$ Const. Court No. 84/2015, 11 June 2015.

${ }^{129}$ Const. Court. No. 96/2018, 19 July 2018. Compare to Joined cases C-203/15 and C-698/15 Tele2 Sverige [2016] ECLI:EU:C:2016:970.

${ }^{130}$ See Velaers 2003, pp. 33-34.

${ }^{131}$ Const. Court No. 106/2004, 16 June 2004. Confirmed in Const. Court No. 10/2007, 17 January 2007, however, without explicitly mentioning the 'Rechtsstaat' principle.

${ }^{132}$ Council of State 22 October 1986, No. 27.050 (Fecosalab).

133 Cass. 26 April 1990, Arr. Cass. 1989-90, 1115.
} 
remains valid and can have consequences: an individual may claim rights conferred by an unpublished law, if he or she meets the conditions laid down in the act. ${ }^{134}$

\subsection{Rights and General Principles of Law in the Context of Market Regulation: Property Rights, Legal Certainty, Non-retroactivity and Proportionality}

2.6.1 These issues have not been discussed at length in Belgian jurisprudence. This is not to say that market regulation has not impacted Belgian jurisprudence. However, in general a Euro-friendly stance has been taken towards EU measures concerning market regulation without fundamental constitutional issues concerning property rights or legal principles such as legal certainty being raised.

If such measures have been considered problematic from a constitutional stance, the issues raised have concerned the compatibility of market regulation with the constitutional provisions regarding the federal structure of Belgium and the checks and balances between the state, region and communities, or with social rights. For example, the balancing of the market freedoms and the right to strike or protest have been considered by certain scholars to fall below the domestic protection of the protection of these rights. ${ }^{135}$

\subsection{The ESM Treaty and the Belgian Constitutional Order}

2.7.1-2.7.3 There has been limited discussion on the constitutionality of the Treaty establishing the European Stability Mechanism (ESM Treaty) or other EU financial regulations following the economic and financial crisis. ${ }^{136}$ In general, the ESM Treaty and other regulations have had only a limited impact on Belgian fundamental rights. During the implementation of the ESM Treaty constitutional arguments were absent from the discussions in Parliament. In general, these new norms did not result in public contestations due to the general Euro-friendly sentiments in Belgian society as well as the limited impact of the EU financial measures on Belgian law.

${ }^{134}$ Council of State 24 February 1987, No. 27.569 (vzw Centrale voor Socialistisch Cultuurbeleid); Council of State 20 November 1956, No. 5.374 (Depaepe).

${ }^{135}$ See Dorssemont and Jaspers 2007, pp. 2-14.

${ }^{136}$ A procedure launched against the act consenting to the ESM Treaty was dismissed by the Constitutional Court as inadmissible for procedural reasons. Const. Court. No. 156/2012, 20 December 2012. 


\subsection{Indirect Judicial Review and the Belgian Judiciary}

2.8.1 The co-operation of Belgian courts with the ECJ in numbers As mentioned, Belgian courts generally adopt a Euro-friendly approach and, thus, Belgian courts regularly refer preliminary questions to the ECJ. For this reason, lawyers and other legal practitioners are well aware of the preliminary reference procedure and will frequently suggest preliminary questions in their legal briefs. In view of this practice, it should not be surprising that several workshops have been organised and publications written to instruct lawyers how to write preliminary questions and convince courts to send these preliminary questions to the ECJ.

As to quantity, the most remarkable feature of the approach by the Belgian judiciary is the number of preliminary references from the Belgian Constitutional Court. The Belgian Constitutional Court is one of the few constitutional courts that sends preliminary questions, and has sent the most preliminary questions of any constitutional court of an EU Member State. ${ }^{137}$ At first, the Constitutional Court was hesitant to refer preliminary questions. ${ }^{138}$ The Court sent its first preliminary question in 1997, hence more than a decade after its establishment. In this case the dispute originated from the different implementation of an EU directive ${ }^{139}$ on the vocational training of general practitioners in the Flemish region and the other regions. ${ }^{140}$ The underlying issue of this dispute was the different treatment between the federalised entities, which was politically highly sensitive. By sending a preliminary reference to the ECJ, the Constitutional Court to a certain extent 'outsourced' the politically sensitive issue. ${ }^{141}$

This first preliminary reference already gives an indication for a hypothesis why the Belgian Constitutional Court frequently refers preliminary questions to the ECJ. The composition of the Constitutional Court is based on a federalist logic whereby judges are picked from the different language groups on the basis of a

\footnotetext{
${ }^{137}$ On the remarkable position of the Belgian Constitutional Court, see Vandamme 2008, pp. 127148.

${ }^{138}$ See Van Nuffel 2005, pp. 46-47.

${ }^{139}$ Council Directive 93/16/EEC of 5 April 1993 to facilitate the free movement of doctors and the mutual recognition of their diplomas, certificates and other evidence of formal qualifications, [1993] OJ L 165/1.

${ }^{140}$ Const. Court No. 6/97, 19 February 1997. The ECJ decided the case in Case C-93/97 Fédération Belge des médecins [1998] ECR I-04855. Final decision of the Constitutional Court in Const. Court No. 120/98, 3 December 1998.

${ }^{141}$ The attraction to outsource such questions became very clear in the tobacco judgment of the Constitutional Court. The Belgian legislation on tobacco advertisement implementing European Directive 98/34/EC highly impacted on the Walloon sports industry, in particular Francorchamps Formula I races. The Constitutional Court in this case did not refer a preliminary question but decided the case itself relying on the applicable EU norms (See Judgment Constitutional Court 30 September 1999, No. 102/1999). However, the Constitutional Court was still reproached for rendering a 'political judgment'. Popelier and Voermans refer to this judgment as a failed attempt to depoliticise the case by relying on EU law. Popelier and Voermans 2015, p. 106.
} 
fixed division of the number of judges. ${ }^{142}$ In consequence, to avoid a deadlock vote between the judges or to find 'external support' for a decision on sensitive issues relating to federalism, it might appear appealing to the Constitutional Court to send a preliminary question to the ECJ.

Since 2003 the Constitutional Court has more frequently referred preliminary questions. ${ }^{143}$ At the time of submission of this report, the Constitutional Court has referred 26 preliminary questions to the ECJ. The website of the Constitutional Court provides a separate section with all the preliminary questions, including references to ECJ judgments as well as the Constitutional Court's referral judgment and final judgment. ${ }^{144}$

The other courts also frequently refer preliminary questions. In total, Belgian courts have sent 739 preliminary references. ${ }^{145}$ The Supreme Court has sent 90 preliminary references, the Council of State has sent 68 preliminary references and the other courts and tribunals have sent 553 preliminary references. Taking into account the relatively small population of Belgium, it is clear that Belgian courts refer preliminary questions more frequently in comparison to other EU Member States. The relatively small number of references by the highest courts in comparison to the lower courts cannot be attributed to a deferential approach of the highest courts. Rather, preliminary questions are in general already sent by the lower courts and thus these issues have in general already been resolved by the time the issues are presented before the highest courts. ${ }^{146}$

2.8.2 The approach towards indirect judicial review The Belgian judiciary has been very open to indirect judicial review by the ECJ. With regard to the relationship between the Belgian highest courts and the ECJ, Belgian authors and judges have frequently labelled this relationship as harmonious or as a judicial dialogue. ${ }^{147}$ When lower courts refer a preliminary question, they will in general simply apply the judgment of the ECJ regarding the preliminary question.

The Constitutional Court, however, will in general not limit itself to a referral to the ECJ judgment. Instead, the Constitutional Court will highlight the reasoning of the ECJ in the preliminary judgment, while adding its own reasoning to come to the

\footnotetext{
${ }^{142}$ For another clear example of outsourcing and Belgian federalism, see the case concerning the social care insurance scheme. See Const. Court Nos. 33/2001, 13 March 2001 and 11/2009, 21 January 2009.

${ }^{143}$ This increase in cases is most probably due to the expansion of the Constitutional Court's scope of review by Parliament in 2003 to the full Title II of the Constitution which includes the vast majority of constitutional rights and freedoms and the Constitutional Court's new approach to interpreting constitutional rights in the light of international fundamental norms, in particular the ECHR (since the Const. Court No. 136/2004, 22 July 2004).

${ }^{144}$ See www.const-court.be.

145 Court of Justice of the European Union, Annual report 2013, Luxembourg 2014, pp. 106-107. Available at www.curia.europa.eu.

${ }^{146}$ See extended analysis Van Nuffel 2010, pp. 1162-1169.

${ }^{147}$ Verrijdt 2012, pp. 89-100; Popelier 2012, pp. 73-98; Van de Heyning 2012, pp. 395-419.
} 
same conclusion based on the parliamentary preparatory works and its own jurisprudence as well as the general jurisprudence of the ECtHR and the ECJ. ${ }^{148}$

2.8.3 For constitutional review by, and statistical data of, the Belgian Constitutional Court, see Sect. 1.1. In particular, in the period 2000-2014, 73\% of the cases were lodged by private parties: $45 \%$ by individuals and $28 \%$ by business entities. A breach of the Constitution was found in $31 \%$ of the judgments in the period 2009-2013 (279 out of 890 judgments): $26.5 \%$ in annulment procedures (65 out of 245 judgments) and 33\% in preliminary decisions (214 out of 645 judgments).

\subsection{Other Constitutional Rights and Principles}

2.9.1 EU law does not only pose challenges to the material protection of fundamental rights, but also to the procedural protection of fundamental rights, in particular protection by the Constitutional Courts. The Belgian system of constitutional rights protection has been challenged by the ECJ case law on the limits to the procedural autonomy of the Member States, sparking a constitutional crisis.

In 2008 the Belgian Parliament introduced a new procedural rule that determined whether ordinary courts were first to submit a preliminary question to the ECJ or the Constitutional Court if concerns arise regarding the compatibility of domestic legislation with a given fundamental right that is partially or fully protected in the Belgian Constitution and in an international treaty, in particular in EU law or the ECHR, in an analogous manner. ${ }^{149}$ The introduction of this rule resulted from a Supreme Court case in which the Court held that it was under no obligation to pose a constitutional question where the constitutional issue concurred with a potential infringement of an equivalent international norm. ${ }^{150}$ It was feared that in every case where a legal norm might conflict with a fundamental right protected analogously by the Constitution and international law, ordinary courts would directly review the compatibility between this provision and international law, circumventing their obligation to send a preliminary question to the Constitutional Court in case of conflict between legislation and the Constitution. Moreover, if the norm under scrutiny fell within the scope of EU law, ordinary courts could prefer to send a preliminary question to the ECJ rather than to the Constitutional Court, reducing the

\footnotetext{
${ }^{148}$ Examples have already been mentioned supra e.g. with regard to the EAW Framework Decision and the Money Laundering Directive. See Sects. 2.3.1-2.3.5 and 2.3.6, respectively. Whether or not this implies the acceptance of primacy of EU law or the Constitution is discussed supra Sects.1.3 and 2.2 as well as infra Sect. 3.2.

${ }^{149}$ Special Act to Amend Art. 26 of the Special Act of 6 January 1989 on the Const. Court, session 2007-2008, No. 4-12/4, 12 June 2008. Available at: www.dekamer.be. On this act and the Belgian war of judges see Velaers 2012, pp. 323-342.

150 Cass. 9 November 2004, No. 04.08949.N; Cass. 16 November 2004, No. 04.0644.N; Cass. 16 November 2004, No. 04.1127.N. Available at: www.juridat.be. On the 9 November 2004 case (Vlaams Blok judgment), see Gors 2005, pp. 509-519.
} 
importance of the Constitutional Court. Therefore, the new procedural rule imposed the chronological priority of the constitutional preliminary question over the preliminary procedure before the ECJ: the ordinary courts were first to send a preliminary question to the Constitutional Court, but remained free to send the question to the ECJ afterwards.

It was questioned whether this priority rule was compatible with EU law. In principle the Member States have extensive discretion with regard to procedural rules. However, when asked to review the compatibility of the French constitutional priority rule in the Melki case, the ECJ developed strict criteria for such priority rules. ${ }^{151}$ The ECJ held that such a priority rule violated EU law if it implied that judges would lose their discretion to refer preliminary questions when they doubted the compatibility of domestic legislation with EU law. ${ }^{152}$ This judgment meant a serious limitation of the procedural autonomy of domestic procedural law in the field of constitutional adjudication. It was questioned whether the Belgian priority rule would survive ECJ scrutiny in the light of the Melki judgment. ${ }^{153}$ The ECJ was asked to review the compatibility of the Belgian priority rule with EU law. Given that the Belgian priority rule was the outcome of lengthy and highly sensitive discussions on the correct balance between the Supreme Court, the Council of State and the Constitutional Court, rejecting the rule as a violation of EU law would seriously undermine relations between the top Belgian courts. However, in Chartry, the ECJ refrained from deciding on the compatibility of the Belgian priority ruling since the underlying subject-matter of the dispute, i.e. taxation of activities carried out within the territory of Belgium, did not fall within the scope of EU law. ${ }^{154}$ In the meantime, the Belgian Parliament amended the priority rule fully in view of the Melki case law.

This episode shows at least the potential for a conflict: whereas the domestic legislator intends to protect the prerogatives of the Constitutional Court, in particular the centralised review of legislation for compatibility with constitutional rights, the ECJ promotes the decentralised review of legislation in order to strengthen the effectiveness of EU law.

\subsection{Common and Individual Constitutional Traditions}

2.10.1-2.10.2 Several of the preliminary references sent by the Belgian Constitutional Court highlight the commonality of the constitutional concerns

\footnotetext{
151 Joined cases C-188/10 and C-189 Melki and Abdeli [2010] ECR I-05667. On this judgment see Dyevre 2012, pp. 318-322.

${ }^{152}$ In this judgment the ECJ developed several requirements to guarantee the discretion of judges. See Velaers 2012, p. 332.

${ }^{153}$ It was argued that the Belgian priority rule fully complied with these criteria. Velaers 2012, p. 338.

${ }^{154}$ Case C-457/09 Chartry v. Belgium [2011] ECR I-00819.
} 
among the constitutional and supreme courts of the Member States. For example, with regard to the preliminary references regarding the EAW, it was clear that several supreme and constitutional courts doubted the compatibility of this Framework Decision and the implementing acts with constitutional rights. While the framing of the constitutional rights might diverge from one country to another, many constitutional and supreme courts were confronted with questions on the compatibility of the EAW implementing acts and constitutional rights. As such, it comes as no surprise that a second constitutional court referred a preliminary question on the constitutionality of fundamental rights and the EAW Framework Decision. $^{155}$

The same is true for the Money Laundering Directive. In almost all European Member States the professional secrecy of lawyers is protected as an essential guarantee for the rule of law. ${ }^{156}$ While this privilege might be interpreted in the different Member States in various manners, under different provisions - the right to a fair procedure and equality of arms, or the protection of privacy, or with different legal bases - constitutional law, ordinary law, jurisprudence or general principles of law, the concern has been shared by many of the highest courts in the European Union. $^{157}$

However, it is unclear whether addressing such issues from the perspective of common constitutional traditions would improve the reception of fundamental rights issues at the level of the ECJ. The examples mentioned not only show the commonality of certain fundamental rights concerns, but also the impact of the ECHR and the ECtHR case law. In both cases, the Belgian Constitutional Court did not so much rely on Belgian constitutional rights, but rather on the Constitution interpreted in the light of the Convention and ECtHR case law. In particular, ECtHR case law has ensured a common understanding of fundamental rights. As a consequence, a clash of EU law and common constitutional traditions often follows from a conflict between EU law and the ECHR. The Belgian Constitutional Court also frames its preliminary questions to the ECJ not as conflicts between EU law and constitutional rights, but as conflicts between EU law and the ECHR.

On the other hand, examples can be provided where a constitutional issue is particular to one or a limited number of Member States. In general, this particularity follows from the specific domestic state structure or historical and societal specificities. With regard to the Belgian context, it is without doubt that the language rights and language regulations following the federalisation of Belgium would be

\footnotetext{
${ }^{155}$ Case C-399/11 Melloni, supra n. 104.

${ }^{156}$ See The Bar of Brussels 2013. Discussion continues regarding to what extent this privilege is also applicable to in-house lawyers. See e.g. in favour Dutch Supreme Court 15 March 2013, LJN: BY6101, while against such extension UK Supreme Court $R$ (Prudential plc \& Anor) v. Special Commissioner of Income Tax \& Anor [2013] UKSC 1.

157 The implementation of the Money Laundering Directive did not result in additional preliminary references, but in the question appearing before the ECtHR in the Michaud case. This case originated from the French implementation of the Directive. Michaud v. France, no. 12323/11, ECHR 2012.
} 
considered a constitutional issue that might trigger the Constitutional Court to revolt against EU law. ${ }^{158}$ As such, the Belgian language rights as protected in the Constitution might be considered as the core of the Belgian constitutional identity. ${ }^{159}$ Such conflict has not yet appeared.

\subsection{Article 53 of the Charter and the Issue of Stricter Constitutional Standards}

2.11.1 There are two possible interpretations of Art. 53 of the Charter. According to the first interpretation, constitutional provisions providing for better protection of fundamental rights than provided by EU fundamental rights case law can limit the application of EU law in the domestic legal sphere. ${ }^{160}$ This interpretation implies a limitation to the primacy of EU law. ${ }^{161} \mathrm{~A}$ second interpretation provides that national courts cannot be compelled to rely on the Charter in cases before them if domestic constitutional provisions or international agreements provide for better protection. As Advocate General Bot has stated: 'Article 53 of the Charter also expresses the idea that the adoption of the Charter should not serve as a pretext for a Member State to reduce the protection of fundamental rights in the field of application of national law'. ${ }^{162}$

The latter interpretation implies no limitation to the primacy of EU law. For this reason, it is without doubt that the latter interpretation will be preferred by the ECJ in view of the primacy doctrine as developed by the ECJ.

However, even in this more restricted interpretation of Art. 53 Charter, it can be expected that this provision will only scarcely be relied upon to resolve conflicts of different fundamental rights standards. Other provisions or interpretational tools appear more successful for providing a margin for the Member States to safeguard a higher level of protection, in particular the margin of discretion as well as the constitutional identity provision. ${ }^{163}$ The underlying reason why such concepts are more attractive than the maximisation clause is that they do not require an assessment of which standard of fundamental rights protection is the highest, suggesting that the other standard is a lower standard of fundamental rights

\footnotetext{
${ }^{158}$ The importance of this issue is for example the reason why Belgium has not ratified the Framework Convention for the Protection of National Minorities by the Council of Europe.

159 On the constitutional identity, see Van de Heyning 2012, at pp. 198-202.

${ }^{160}$ Such interpretation was implied in the preliminary question of the Spanish Constitutional Court regarding the limitation to the EAW framework decision on the basis of a better protection of suspects in cases involving trials in absentia. Spanish Constitutional Court Auto 86/2011, 9 June 2011 (Melloni judgment).

${ }^{161}$ It has been argued that this was by no means the intention of the drafters. See for an overview Ladenburger 2012, pp. 174-175.

162 Opinion of AG Bot, in Case C-399/11 Melloni [2011] ECLI:EU:C:2012:600, para. 133.

${ }^{163}$ Article 4 para. 2 TEU.
} 
protection. Rather, these concepts imply the particularity of a given system for which in a given circumstance and to a limited extent an exception to EU law can be provided.

It is probably due to this reason that its equivalent in the Convention, namely Art. 53 ECHR, has only been referred to by the ECtHR in a limited number of cases. ${ }^{164}$ The ECtHR developed the doctrine of the margin of appreciation to provide for some flexibility and room for manoeuvre for the Member States and courts to uphold a domestic standard of fundamental rights protection.

The maximisation provision has not been relied upon frequently in domestic case law either. In the Belgian case law, the Supreme Court has only on one occasion explicitly referred to Art. 53 ECHR to refute an objection against the application of the domestic interpretation of the right to a trial before an independent judge. It was held that the Belgian interpretation was stricter than the interpretation provided by the ECtHR. The Supreme Court relied upon Art. 53 ECHR to find that a national court could provide for stricter criteria than the ECtHR when reviewing the independence of a judge as protected under Art. 6 ECHR. ${ }^{165}$

The Constitutional Court has made several references to Art. 53 ECHR with rather diverse outcomes. ${ }^{166}$ In most cases the reference to this article has not had any impact on the actual judgment. ${ }^{167}$ In one case the Constitutional Court relied on Art. 53 ECHR to decide that the provisions in the ECHR and international law on the right to marriage could not be interpreted so as to restrict the domestic legislator from extending the right to marriage to homosexual couples. ${ }^{168}$ In another judgment the Constitutional Court held that a reference to Art. 53 ECHR could not be relied upon to extend the interpretation of an ECHR provision. ${ }^{169}$ Finally, in a number of judgments the Constitutional Court held that Art. 53 ECHR implied that the domestic legislator was both to uphold the material interpretation of the legality principle as entrenched in the ECHR (legislative norms must be accessible and foreseeable) as well as the formal interpretation entrenched in the Belgian Constitution (interference of rights must be based upon a statute). ${ }^{170}$ In these cases, the Court effectively relied on Art. 53 ECHR to combine constitutional and conventional protection in order to strengthen fundamental rights protection. ${ }^{171}$

\footnotetext{
${ }^{164}$ See on this issue Liisberg 2001.

165 Cass. (2e k.) 11 December 1996, AR P.96.1460.F (Benaïssa/Dutroux).

${ }^{166}$ For an overview, see Popelier and Van de Heyning 2011, pp. 495-536.

${ }^{167}$ Const. Court No. 77/94, 18 October 1994; Const. Court No. 34/96, 15 May 1996; Const. Court No. 76/96, 18 December 1996; Const. Court No. 49/2001, 18 April 2001; Const. Court No. 33/94, 26 April 1994.

168 Const. Court No. 159/2004, 20 October 2004.

${ }^{169}$ Const. Court No. 81/95, 14 December 1995. In this case the European Commission had explicitly stated that compulsory military service should not be regarded as forced labour under Art. 4 ECHR. The Constitutional Court stated that Art. 53 ECHR did not alter this finding.

${ }^{170}$ Const. Court No. 202/2004, 21 December 2004; Const. Court No. 131/2005, 19 July 2005; Const. Court No. 151/2006, 18 October 2006.

${ }^{171}$ Popelier 2011, p. 166.
} 


\subsection{Democratic Debate on Constitutional Rights and Values}

2.12.1-2.12.3 The stance of the public as well as the political class vis-à-vis EU law and the European Union more in general has been labelled in the literature as a permissive consensus. ${ }^{172}$ In general, political parties take a pro-European stance. Research shows that political parties vote in large majorities in favour of the ratification and implementation of EU norms. ${ }^{173}$ Also, public debate regarding the limits of EU law in the Belgium domestic sphere is exceptional. ${ }^{174}$ Consequently, the question whether EU law may restrict constitutional rights and values is only occasionally debated in view of a specific directive or new judgment of the ECJ, and in general, the debate is limited to human rights organisations or professional actors, such as the Belgian Bars of Lawyers in view of EU norms touching upon the protection of procedural rights. It appears that more political debate on the EU has emerged due to the financial and economic crisis and the budgetary measures taken by the EU. ${ }^{175}$ In these discussions the central question is not so much whether more or less Europe is needed, but rather whether a more social or liberal approach should be taken. However, there is no conclusive research to date to support the claim that the renewed political interest in EU politics has also triggered public debate on EU issues and the limits of the EU. The 2014 barometer of the European Commission does not show an increased interest in European politics. ${ }^{176}$ On the other hand, a high number of Belgian citizens replied that they agreed with the statement that economic reforms would be more effective if they were co-ordinated on the European level. ${ }^{177}$ Thus, Belgian public opinion could be described as 'EU-friendly but uninterested'.

Specifically with regard to the drafting of the EAW, there was only limited public engagement. However, several public actors did raise constitutional issues during the drafting process, in particular human rights institutions such as the

\footnotetext{
${ }^{172}$ Whereas this position of permissive consensus changed in many Member States after the Maastricht Treaty, this position has not altered in Belgium. Bursens et al. 2010, pp. 16-22 and Beyers 1998.

${ }^{173}$ Bursens, et al. 2010, pp. 19-21.

174 The permissive consensus in Belgium does not imply a great interest in EU issues in public debate. In general terms, research shows that public debate on EU issues or interest in EU politics is very limited, in contrast to domestic political issues. See Bursens 2002 and Eurobarometer of the European Commission 81, Tables of Results July 2014, p. 83. In this Eurobarometer the Belgian public scored very low on the question on whether one would discuss European politics with friends or relatives. Only $8 \%$ answered 'frequently' and $45 \%$ responded 'never'. Belgium is among the lowest scoring countries of the EU on this issue.

175 This is particularly true for the so-called six-pack measures of the EU. See e.g. (2012, March 8) Belgian minister vows to resist 'ultra-liberal' Commission. Euractiv. http://www.euractiv.com/ euro-finance/commission-reproached-tough-belgium-news-511398.

${ }^{176}$ Eurobarometer of the European Commission 81, Tables of Results July 2014, p. 83.

${ }^{177}$ Standard Eurobarometer of the European Commission 81, Report July 2014, p. 62.
} 
Human Rights League as well as the Belgian Bars of Lawyers. In general, the Belgian Bars have been very active with regard to the implementation of EU law in Belgian law when relevant to criminal proceedings and procedural rights. ${ }^{178}$

\subsection{Experts' Analysis on the Protection of Constitutional Rights in EU Law}

2.13.1-2.13.4 On the basis of the Belgian experience, no univocal answer can be given to the question of whether EU law increases or decreases the standard of human rights protection. In certain cases, ECJ case law might result in a decrease, while in other cases in an increase, of fundamental rights standards at the domestic level.

In particular in the area of criminal proceedings, concern has been voiced regarding the impact of EU law, including ECJ case law, on the domestic level of protection of the procedural rights of suspects. Examples that have been mentioned above include the impact on the legal privilege of lawyers following adoption of the Money Laundering Directive and the procedural safeguards for suspects and accused persons following the introduction of the EAW. ${ }^{179}$

In other areas of law, however, it has also been noted that EU law, including ECJ case law, has improved the level of protection. With regard to the Belgian legal order, this has particularly been the case with regard to age and gender discrimination. The Test-Achats case is a well-known example. ${ }^{180}$ The EU Directive in question intended to end all discrimination on the basis of gender in the insurance sector. ${ }^{181}$ The EU, however, succumbed to pressure from the Member States to include a derogation in the directive allowing Member States to use gender as an actuarial factor for insurance services. The Belgian Parliament relied on this exemption when implementing the directive into Belgian law, allowing for insurance companies to use gender as a factor in calculating insurance premiums and benefits. ${ }^{182}$ The Constitutional Court was requested to decide on the compatibility

\footnotetext{
178 The Belgian Bars have raised constitutional challenges regarding several domestic acts raising preliminary questions before the ECJ, most notably the Money Laundering Directive and more recently with regard to the introduction of VAT on legal fees. Const. Court No. 126/2005, 13 July 2005; Const. Court No. 165/2014, 13 November 2014.

${ }^{179}$ See Sects. 2.3.6 and 2.3.1-2.3.5, respectively.

${ }^{180}$ Other directives also had an important impact on the protection against discrimination on the basis of race or gender in Belgium, in particular Directive 2000/78/EC of 27 November 2000, establishing a general framework for equal treatment in employment and occupation [2002] OJ L $303 / 16$

${ }^{181}$ Council Directive 2004/113/EC of 13 December 2004 implementing the principle of equal treatment between men and women in the access to and supply of goods and services, [2004] OJ L $373 / 37$.

${ }^{182}$ Act of 10 May 2007 combating discrimination between men and women, Official Gazette 31 December 2007.
} 
of this exemption with the prohibition on discrimination. The Court decided to refer a preliminary question to the ECJ. ${ }^{183}$ The ECJ decided that Member States could not allow for derogations from the prohibition to use sex as an actuarial factor for insurance services, rendering the exemption in the directive invalid. ${ }^{184}$ The Constitutional Court in consequence struck down the provision in the domestic act based on this exemption. ${ }^{185}$

An interesting aspect of the impact of the ECJ on the standard set for constitutional rights is its harmonising effect on the case law of the Belgian Constitutional Court and Supreme Court. In the past both courts have frequently disagreed on the interpretation of certain constitutional provisions, resulting in divergent case law. It has been noted in the past that in this respect, supranational law has played the role of pacifier between the highest courts. In general this has implied that the Supreme Court has amended its case law in line with Constitutional Court case law, given that the Constitutional Court already interprets constitutional rights in line with the case law of the ECtHR and the ECJ.

While in previous cases the Strasbourg case law has played this role of pacifier, it was ECJ fundamental rights case law that most probably ended a divergence between the Constitutional Court and the Supreme Court on the interpretation of the principle that no legal action can be instituted twice for the same cause of action (the non bis in idem principle) in criminal proceedings, if one of the two proceedings would be qualified under Belgian law as an administrative proceeding (e.g. fiscal or deontological matters). Whereas the Constitutional Court held - in line with the applicable ECtHR case law - that this principle applies whenever the underlying facts are identical or substantially the same, ${ }^{186}$ the Supreme Court would only accept that this principle applies when the crimes for which the person was prosecuted were drafted in the same wording and mentioned the same constitutive elements. ${ }^{187}$ The Supreme Court finally amended its case law in line with the Constitutional Court and ECtHR jurisprudence. The reason for this change is attributed to ECJ case law, in particular the Akerberg Fransson case, in which the ECJ clearly stated that the non bis in idem principle applies in case of identical or substantially the same facts. ${ }^{188}$ Following this line of case law of the ECJ, the Supreme Court finally altered its position. ${ }^{189}$ This provides evidence of the persuasive power of ECJ case law as well as the harmonising effect this case law can have on domestic fundamental rights protection.

\footnotetext{
183 Const. Court No. 103/2009, 18 June 2009.

${ }^{184}$ Case C-236/09 Association Belge des Consommateurs Test-Achats and others [2011] ECR I-00773.

185 Const. Court No. 116/2011, 30 June 2011.

186 Const. Court 29 July 2010, No. 91/2010 and Const. Court 19 December 2013, No. 181/2013.

${ }^{187}$ Supreme Court 24 January 2002, Supreme Court 11 January 2012 and Supreme Court 27 March 2013, available at www.cass.be.

188 Case C-617/10 Akerberg Fransson [2013] ECLI:EU:C:2013:105.

${ }^{189}$ Supreme court 17 June 2014, available at www.cass.be.
} 


\section{Constitutional Issues in Global Governance}

\subsection{Constitutional Rules on International Organisations and the Ratification of Treaties}

3.1.1-3.1.2 The enabling clause of Art. 34 of the Constitution, discussed in Part 1, is a general clause. It regulates the transfer of powers to all international organisations, not merely the European Union. It will be recalled that a simple majority in Parliament suffices, unless the treaty contradicts the Belgian Constitution, in which case a prior amendment of the Constitution is necessary before ratification. Also, in the case of 'mixed treaties', containing provisions within the spheres of competence of both the federal and the federated entities, the approval of all competent parliaments is required.

3.1.3-3.1.4 See also Part 1 for (unsuccessful) proposals to introduce treaty referendums. In addition to those mentioned above, scholars have regularly made proposals to simplify the constitutional amendment procedure in order to facilitate the ratification of treaties which contradict the Constitution. ${ }^{190}$ Occasionally, this has been translated into a legislative proposal. ${ }^{191}$ The idea is to do away with the intermediate renewal of Parliament. This would reinforce the efficacy approach discussed above. These proposals, however, have never seriously been discussed in Parliament.

\subsection{The Position of International Law in National Law}

3.2.1-3.2.2 The Constitution is silent about the position of international law in the domestic legal order, despite several efforts that have been undertaken since the 1950s to determine the relation between Acts of Parliament and the Constitution. ${ }^{192}$ As mentioned, a monist position, establishing the primacy of self-executing international law over national law, was opted for by the Supreme Court in its Franco Suisse Le Ski judgment. ${ }^{193}$ By assuming the power to disregard Acts of Parliament,

${ }^{190}$ For an overview of advocates of this proposal, see Blero 2011, p. 43. Most recently: Van Assche 2012, p. 447.

191 E.g. Parl. Doc., Senate, 2010-2011, No. 5-281/1. The Council of State, Legislation Division, also supports this idea: Advice of 21 December 2004 of the general assembly, Parl. Doc. Senate 2004-2005, No. 3-1091/1, 532 and Advice of 18 January 2008 of the general assembly, Parl. Doc. Senate 2007-2008, No. 4-568/1, 343.

192 E.g. Parl. Doc. House, 1952-1953, No. 693, 54-55; Parl. Doc. House, 1959-1960, No. 374/1; Parl. Doc. Senate, 1978-1979, 476/2; Parl. Doc. House, 1978-1979, 519/4, 12; Parl. Doc. Senate, 1991-1992, 626/1.f.

193 Cass. 27 May 1971, (1971) Pas. I, 886. 
it tacitly amended the Constitution. ${ }^{194}$ We recall that the case in point concerned EEC law, but the primacy rule was established regarding all international law. According to the Court, this is a general principle of law, ${ }^{195}$ inherent to the 'nature' of international law. The Constitutional Court embraced this stance, adding that in the case of abstract review, the provisions do not have to be self-executing for a treaty to have primacy over a national statute or regulation. ${ }^{196}$

More controversial is the question of whether international law also has precedence over the Constitution. As mentioned above, both the Supreme Court and the Council of State accept the precedence of EU law over the Constitution. The Supreme Court has also explicitly declared the primacy of the ECHR over the Constitution. ${ }^{197}$ The Constitutional Court's stance, however, is less clear. As mentioned in Part 1, the Constitutional Court has assumed the power to review laws giving assent to treaties against the Constitution, not only pursuant to annulment requests (which have to be lodged 60 days after publication of the Act of assent) but also in preliminary judgments. ${ }^{198}$ This has given rise to heated debate in doctrine, as it was considered to detract from the traditional monist position. ${ }^{199}$ Although the Constitutional Court, formally, assesses the Act giving assent, in reality it reviews the content of the treaty, as implemented in the domestic legal order through the Act of assent, against the Constitution. In a monist approach and from an international law perspective, judicial review is excluded once Belgium has ratified a treaty, with one exception based on Art. 46 of the Vienna Convention on the Law of Treaties: if the State's consent to be bound by the treaty manifestly violated a fundamental internal rule regarding its competence to conclude treaties. ${ }^{200}$ In doctrine, the Constitutional Court's approach was considered - and often applauded ${ }^{201}$ - as giving precedence to the Constitution over international treaties. Other doctrine, while generally accepting the precedence of EU law, argues in favour of the precedence of constitutional law over other international law. ${ }^{202}$ In reality, the Constitutional Court has never taken an explicit stance. When reviewing an Act giving assent to a treaty, it merely examines - from a constitutional, not an international point of view - whether Parliament's consent, at the time of entry, was in conformity with the Constitution, which it considers a requirement for the treaty to

\footnotetext{
${ }^{194}$ Bossuyt and Verrijdt 2011, p. 356.

195 Cass., 5 Dec. 1994, Arr. Cass., 1994, 1055.

196 Const. Court No. 106/2003, 22 July 2003.

197 Cass. 9 November 2004, (2005) Rev.belge de Dr. Const. 507; Cass. 16 November 2004 (2005) Rechtskundig Weekblad 387.

${ }^{198}$ For the first time in Const. Court. No. 26/91, 16 October 1991.

${ }^{199}$ Several scholars consider the Constitutional Court's stance to be a return to a dualist approach, e.g. Van Assche 2012, p. 440.

${ }^{200}$ Van Assche 2012, pp. 442-444; Velu 1992, p. 147.

${ }^{201}$ Bombois 2004, pp. 143-150; Bribosia 1996, p. 76; Brouwers and Simonart 1995, pp. 13-17; Lejeune and Brouwers 1992, p. 674; François 2005, pp. 261-266; Meersschaut 2003, p. 50; Naome 1994, p. 55.

${ }^{202}$ Alen 2007, pp. 105-113; Delpéréé 2004, pp. 167-180; Jamart 1999, pp. 128-129.
} 
take effect in the domestic legal order. ${ }^{203}$ Bossuyt, the former president of the Constitutional Court, has even argued that the Constitution as well as all highest courts (Supreme Court, Council of State and Constitutional Court) should avoid taking an explicit stance on the primacy of either constitutional or international law, to prevent a guerre des juges. ${ }^{204}$

It is striking that this debate has often been held in terms of monism and dualism, whereas in reality legal systems employ a more nuanced approach in between these extremes. ${ }^{205}$ Traditionally, proponents of a monist approach have adhered to a form of 'progressive internationalism', while dualism has been linked with the theory of state sovereignty. ${ }^{206}$ Today, the growing sympathy for a more dualist approach in Belgian doctrine does not necessarily express a nostalgic yearning for a lost sense of sovereignty. Rather, it aligns with concerns for the respect of domestic values and principles in a globalising world.

Meanwhile, the idea that supranational law and national constitutional law are part of one multilevel constitutional system and European and domestic courts should find some equilibrium through judicial dialogue, is slowly gaining ground in Belgian doctrine. ${ }^{207}$ In practice, however, judicial dialogue with the ECJ and the European Court of Human Rights is limited. On the one hand, the Belgian courts, including the Constitutional Court, readily implement and quote European case law and refer preliminary questions to the ECJ. The European Convention on Human Rights and the case law of the ECtHR have particular influence in the Belgian legal order. The Constitutional Court interprets constitutional rights in conformity with treaty rights, considering them an 'inextricable unity'. ${ }^{208}$ While this concerns all international treaties and especially the UN fundamental rights treaties are often invoked, the ECHR is of special importance. The Constitutional Court regularly quotes Strasbourg case law, by which it feels bound, ${ }^{209}$ and once even waited for the Grand Chamber's decision, in the Hirst case, before giving its own judgment. ${ }^{210}$ On the other hand, the Belgian courts hardly ever criticise the European Courts' rulings, ${ }^{211}$ even when they feel reluctant towards specific case law, such as the

${ }^{203}$ Beirlaen 1992; Bossuyt 2012, pp. 427-429; Popelier 2007, pp. 228-238; Velaers 2008, pp. 112-116.

${ }^{204}$ Bossuyt 2012, p. 427.

${ }^{205}$ Franckx and Smis 2006, p. 123; Feyen 2008, p. 177.

${ }^{206}$ Franckx and Smis 2006, p. 125.

207 Alen, Muylle and Verrijdt 2012, pp. 6-11; Bossuyt and Verrijdt 2011, pp. 365-366; Popelier 2012, pp. 73-99; Van Meerbeeck and Mahieu 2007, pp. 79-88.

${ }^{208}$ For the first time in Const. Court No. 136/2004, 22 July 2004.

${ }^{209}$ Alen et al. 2012, p. 25; Lavrysen and Theunis 2013, p. 354.

${ }^{210}$ Martens 2010, p. 352.

${ }^{211}$ Alen et al. 2012, p. 16; Popelier 2012, p. 83. The Bressol case is a rare exception where the Constitutional Court openly disagreed with the ECJ on whether the financial implications of students from other Member States could justify measures restricting access to higher education on the basis of nationality, Const. Court No. 89/2011, 31 May 2011. 
Salduz case $\operatorname{law}^{212}$ or the nationality requirement for enjoying social security allowances. ${ }^{213}$ Most of the time, conversations with the European Courts are one-sided. As a result, the courts are not successful in bringing domestic arguments to the fore at the European level. ${ }^{214}$

\subsection{Democratic Control}

3.3.1 The Belgian Constitution does not provide for parliamentary participation in the conclusion of international agreements or the entry into international organisations, other than giving assent by a simple majority or, in the case of EU treaties, the information obligations mentioned above. The referendum ban, discussed in Part 1, also applies in the case of international treaties.

Apart from the occasional proposals mentioned above, submitting the conclusion of international agreements to a referendum and tightening democratic control are not on the agenda in academic or political circles. Instead, as mentioned, proposals to simplify the constitutional amendment procedure if constitutional amendment is necessary for ratifying a treaty, occasionally pop up.

Meanwhile, the requirement that, in the case of mixed treaties, all competent Parliaments have to give assent, has hindered the ratification of specific human rights treaties. Belgium has signed but not ratified both the Framework Convention for the Protection of National Minorities and Protocol No. 12 ECHR, because these treaties did not get the approval of the Flemish Parliament. Flemish politicians fear that these treaties might thwart linguistic balances which they consider to be vital to the stability of the divided Belgian state.

\subsection{Judicial Review}

3.4.1 Belgian courts do not have the power to review treaties and measures adopted under international law. However, as mentioned above, the Constitutional Court reviews treaties indirectly, through the Acts giving assent to these treaties. Proponents of the monist tradition have criticised this practice for violating the pacta sunt servanda principle. $^{215}$ On the other hand, denying the Court the right to assess whether a treaty was in conformity with the Constitution at the time of its ratification would allow the Government to circumvent, with a simple majority in Parliament, fundamental rights and principles laid down in the Constitution.

\footnotetext{
212 Popelier 2012, p. 91.

213 Alen et al. 2012, pp. 31-32.

214 Popelier 2012, p. 99.

215 Bossuyt 2012, p. 424; Velu 1992, pp. 101-102.
} 
We recall that Parliament interfered by denying the Constitutional Court the power to answer preliminary references regarding Acts of Parliament giving assent to EU treaties and to the ECHR and its Protocols. The limitation to these European treaties was heavily criticised in doctrine as well as by the advisory legislation division of the Council of State. ${ }^{216}$ Indeed, Parliament's argument that interference was necessary to safeguard stability in international relations does not justify the distinction from other international treaties. Instead, proposals were launched in doctrine to complement the current prior advice provided by the Council of State on the constitutionality of treaties with an optional (or even obligatory), prior and binding judgment by the Constitutional Court. ${ }^{217}$ Such proposals, however, have never been considered by Parliament.

\section{5-3.6 The Social Welfare Dimension of the Constitution, and Constitutional Rights and Values in Selected Areas of Global Governance}

3.5.1-3.6.1 While the effectiveness of institutions of global economic governance is debated in Belgian scholarship, the effects on constitutional protection of social welfare, constitutional rights and values seem more or less neglected. In literature, the proliferation of regulatory agencies that enjoy political independence has been discussed as an 'international impulse' trend that runs counter to domestic principles of representative democracy. ${ }^{218}$ Again, the Constitutional Court seems to easily accept this if EU rules prescribe this type of independence. The Council of State has referred to the Constitutional Court the question of whether the conferring of broad powers to the Electricity and Gas Regulator (CREG), directly affecting citizens, violated the Constitution, as this agency's board does not consist of Government members that are controlled by an elected Parliament. The Constitutional Court rejected the claim, arguing that the CREG's decisions were submitted to full and independent judicial control by the judicial branch of the Council of State, and that the CREG was under the obligation to write an annual activity report for the Government, providing Parliament with a means of control. Interestingly, the Constitutional Court added that even if these arguments were not to be considered sufficient to justify the challenged Act in view of Arts. 33 and 37 of the Belgian Constitution, then the Act still found a basis in Art. 34 of the Constitution, which allows for a transfer of powers to supranational organisations, since the conferral of such powers to an independent agency was based on EU law. ${ }^{219}$

\footnotetext{
${ }^{216}$ Council of State, Advice of 25 April 2000, Parl. Doc., Senate 2000-2001, No. 2-897/1, 26-30; Bombois 2004, pp. 154-155; Van Assche 2012, p. 441.

${ }^{217}$ Van Assche 2012, pp. 446-447.

${ }^{218}$ See in particular De Somer 2014.

${ }^{219}$ Const. Court No. 130/2010, 18 November 2010.
} 
Critical comments did arise regarding the human rights issues following from the inclusion of persons on a terrorist blacklist and the sanctions following such listing, such as the freezing of bank accounts and a travel ban. ${ }^{220}$ The UN blacklist included three Belgians, including a couple suspected of financing Al-Qaida through the humanitarian organisation Global Relief Foundation. After more than two years, no evidence or criminal charges were brought against them. The Brussels Tribunal of First Instance therefore ordered the Belgian state to start the de-listing procedure. The Belgian state, however, was unable to obtain the removal of the Belgian couple from the blacklist. Eventually, the Human Rights Committee concluded that Art. 17 of the International Covenant on Civil and Political Rights and Arts. 12 and 17 of the Optional Protocol to the Covenant had been violated. ${ }^{221}$ In particular, it reproached the Belgian state for transmitting the couple's names to the Sanctions Committee, without waiting for the outcome of the criminal investigation that was initiated at the request of the Public Prosecutor's office. It admitted that the state was unable to remove the names from the list, but imposed upon the state the duty 'to do all it can to have their names removed from the list as soon as possible, to provide the authors with some form of compensation and to make public the requests for removal' and 'to ensure that similar violations do not occur in the future'.

Despite, on the one hand, the far-reaching implications of the procedure and sanctions on constitutional rights, and, on the other, the excavation of state sovereignty, there was no heated parliamentary debate on the subject. UN resolutions and EU acts were implemented through executive decrees. The Senate did initiate a debate regarding the subsidiarity and proportionality of an EU framework decision on combating terrorism, leading to some critical comments. ${ }^{222}$ As for the specific case of terrorist blacklists, the Belgian example shows that even if domestic courts express human rights concerns and impose upon the state the duty to request de-listing, it is not within the power of the national authorities to actually secure constitutional rights. ${ }^{223}$ This is disquieting to say the least, and calls for discussion at the UN level.

\section{References}

Alen A. (1984) Rechter en bestuur in het Belgische Publiekrecht (Judge and administration in Belgian Public Law). Kluwer, Antwerp.

Alen A. (1995) Handboek van het Belgisch Staatsrecht (Manual of Belgian constitutional law). Kluwer, Antwerp.

Alen A. (2007) De Grondwet, hoogste rechtsnorm? (The Constitution, supreme norm?). In: En hommage à Francis Delpérée. Itinéraires d'un constitutionnaliste, Brussels, Bruylant, pp. 105-113.

\footnotetext{
${ }^{220}$ See amongst others, Dehert and Weis, pp. 242-259 and Dewulf and Paquée 1999, pp. 607-640.

${ }^{221}$ Human Rights Committee, Communication No. 1472/2006, 29 December 2008.

${ }^{222}$ Parl. Doc. Senate 2007-2008, 508/1.

${ }^{223}$ See also Dewulf and Paquée 1999, 635.
} 
Alen A. (2012) Handboek van het Belgisch Staatsrecht (Manual of Belgian Constitutional Law). Kluwer, Deurne.

Alen A., Muylle K., Verrijdt W. (2012) De verhouding tussen het Grondwettelijk Hof en het Europees Hof voor de rechten van de mens (The relation between the Constitutional Court and the European Court of Human Rights). In: Alen A., Van Nieuwenhove J. (eds.) Leuvense Staatsrechtelijke Standpunten: De Europese Dimensie in het Belgische Publiekrecht (Constitutional stances from Louvain: the European dimension in Belgian Public Law). Die Keure, Bruges, pp. 1-45.

Beirlaen A. (1992) Omtrent de verhouding tussen het internationaal en het Belgische recht (About the relation between international and Belgian law). In: Présence du droit public et des droits de l'homme: mélanges offerts à Jacques Vélu. Bruylant, Brussels, pp. 141-151.

Beyers J. (1998) Permissieve consensus, maatschappelijk debat en het draagvlak van de Europese Unie bij de Belgische maatschappelijke organisaties (Permissive consensus, public debate and foundation for the European Union among Belgian societal organisations). Res Publica 50:247-272.

Blero B. (2011) L'article 195 de la Constitution, une pierre angulaire à retailer. In: De Becker A., Vandenbossche E. (eds.) Eléments clés ou éléments charnières dans la Constitution. Die Keure, Bruges, pp. 1-57.

Bombois T. (2004) La restriction des competences de la Cour d'Arbitrage à l'égard des traités internationaux. In: Rasson-Roland A., Renders D., Verdussen M. (eds.) La Cour d'Arbitrage vingt ans après. Bruylant, Brussels, pp. 143-150.

Bossuyt M. (2012) De verhouding tussen de Belgische Grondwet en verdragen (The relation between the Belgian Constitution and treaties). Revue belge de droit international 45: 423-430.

Bossuyt M., Verrijdt W. (2011) The Full Effect of EU Law and Constitutional Review in Belgium and France after the Melki Judgment. EuConst. 7:355-391.

Bribosia H. (1996) Applicabilité directe et primauté des traités internationaux et du droit communautaire. Revue belge de droit international 76:33-89.

Bribosia H. (1998) Report on Belgium. In: Slaughter A.M., Stone Sweet A., Weiler J.H.H. (eds.) The European Court and National Courts - Doctrine and Jurisprudence. Hart Publishing, Oxford, pp. 1-39.

Brouwers P., Simonart H. (1995) Le conflit entre la constitution et le droit international conventionnel dans la jurisprudence de la Cour d'arbitrage. Cahiers de droit Européen 31:13-17.

Brussels Bar (2013) Professional secrecy of lawyers in Europe. Cambridge University Press, Cambridge.

Bursens, P. (2002) Belgium's Adaptation to the EU: does federalism constrain Europeanisation. Res Publica 54:549-598.

Bursens P., Drieskens E., Van Hecke S. (2010) The Belgian Presidency: Driving in the EU's Back Seat. Swedish Institute for European Policy Studies, Stockholm, pp. 16-22.

Cloots E. (2008) Het Grondwettelijk Hof en de toetsing van secundair unierecht aan fundamentele rechten (The Constitutional Court and the review of secondary Union law against fundamental rights). In: Alen A., Van Nieuwenhove J. (eds.) Leuvense Staatsrechtelijke Standpunten (Constitutional stances of Louvain). Die Keure, Bruges, pp. 17-54.

Craenen G. (1993) België in het buitenland. De nieuwe regeling van de buitenlandse betrekkingen (Belgium and abroad. The new regulation of international relations). In: Alen A., Suetens L.P. (eds.) Het federale België na de vierde staatshervorming (Federal Belgium after the fourth state reform). Die Keure, Bruges, pp. 59-103.

Craig P. (2004) The ECJ, National Courts and the Supremacy of EU law. In: Pernice I., Miccu R. (eds.) The European Constitution in the Making. Nomos Verlag, Baden-Baden, pp. 35-51.

De Somer S. (2014) International and European Impulse with regard to the Creation of Autonomous Public Bodies: An Emerging Trend. UCL Journal of Law and Jurisprudence 3:58-86.

Dehert P., Weis K. (2009) Europese terrorismelijsten. Beperkte rechtsbescherming (European terrorism lists. Limited legal protection). NJW 8:242-259.

De Jaegere J. (2017) The deliberative performance of the Belgian Constitutional Court in a consociational system: an empirical analysis. Ph.D. thesis, University of Antwerp. 
Delpérée F. (2004) Autour d'un sanctuaire. In: Mélanges J. Van Compernolle. Bruylant, Brussels, pp. 167-180.

Dewulf S., Paquée D. (1999) Protecting human rights in the war on terror: challenging the sanctions regime originating from resolution 1267. Neth. Q. Hum. Rts. 24:607-640.

Dorssemont F., Jaspers T. (2007) Collectieve actie en vrij verkeer: eindigen grondrechten waar 'fundamentele vrijheden' beginnen? (Collective action and free movement: do fundamental rights end where 'fundamental freedoms' begin?). NJW 6:2-14.

Dujardin J., Vandelanotte J., Goedertier G., Goossens J. (2014) Basisbegrippen publiekrecht (Basic concepts of public law). Die Keure, Bruges.

Dyevre (2012) The Melki way: the Melki case and everything you always wanted to know about French judicial politics (but were afraid to ask). In: Claes M., Popelier P., De Visser M., Van de Heyning C. (eds.) Constitutional Conversations. Intersentia, Antwerp, pp. 309-321.

Elchardus M., Te Braak P. (2014) Toekomstverwachtingen van jongvolwassenen - Rapport 6. De toekomstwensen en - verwachtingen betreffende de Europese Unie (Future perspectives of young adults). http://socipc1.vub.ac.be/torwebdat/publications/t2014_51.pdf.

Feyen S. (2008) Verdragsrechtelijke inwerking (Legal effects of treaties). Chroniques de Droit Public 15:167-204.

Franckx E., Smis S. (2006) Doorwerking van internationaal recht in de Belgische en Russische rechtsorde: een rechtsvergelijkende analyse (Legal effects of international law in the Belgian and Russian legal orders: a comparative analysis). In: Wouters J., Van Eeckhoutte D. (eds.) Doorwerking van internationaal recht in de Belgische rechtsorde (Legal effects of international law in the Belgian legal order). Intersentia, Antwerp, pp. 119-137.

François L. (2005) Le recours à une philosophie du droit dans la motivation des décisions juridictionnelles. Journal des tribunaux 124:261-266.

Gilissen, J. (1968) La Constitution belge de 1831: ses sources, son influence. Res Publica 107:107-141.

Gors B. (2005) Une Cause de refus de renvoi préjudiciel: la primauté de la convention Européenne sur la constitution. Revue Belge de droit constitutionnel 12:509-519.

Ingelaere F. (1994) De Europeesrechtelijke raakvlakken van de nieuwe wetgeving inzake de internationale betrekkingen van de Belgische Gemeenschappen en Gewesten (Interfaces of the new law on international relations of Belgian communities and regions with European law). S. E.W. 42:67-82.

Jamart J.S. (1999) Observations sur l'argumentation: la primauté du droit international. Revue Belge de Droit Constitutionnel 6:109-136.

Ladenburger C. (2012) European Union Institutional Report. In: Laffranque J. (ed.) The Protection of Fundamental Rights Post-Lisbon, Reports of the XXV FIDE Congress Tallinn 2012, Vol. 1. Tartu University Press, Tallinn, pp. 141-215.

Lavrysen L., Theunis J. (2013) The Belgian Constitutional Court: a Satellite of the ECtHR? In: Alen A., Joosten V., Leysen R., Verrijdt W. (eds.) Liberae Cogitationes: Liber Amicorum Marc Bossuyt. Intersentia, Antwerp, pp. 331-354.

Lejeune Y., Brouwers P. (1992). La Cour d'arbitrage face au contrôle de la constitutionnalité des traités. Journal des tribunaux 112:670-676.

Liisberg B. (2001) Does the EU Charter of Fundamental Rights Threaten the Supremacy of EU law?) L.L.M. Paper, Jean Monnet program 4/01, NYU School of Law, New York.

Louis J.V. (1970) L'article 25bis de la Constitution Belge. R.M.C. 12:410--416.

Martens P. (2010) L'influence de la jurisprudence de la Cour européenne des droits de l'homme sur la Cour constitutionnelle. Chroniques de droit public 17:350--358.

Mast A., Dujardin J. (1985) Overzicht van het Belgisch Grondwettelijk Recht (Overview of Belgian constitutional law). Story-Scientia, Ghent.

Meersschaut F. (2003) De ondraaglijke lichtheid van de Grondwet (The unbearable lightness of the constitution). Tijdschrift voor bestuurswetenschappen en publiekrecht, pp. 48-51.

Naome C. (1994) Les relations entre le droit international et le droit interne belge après l'arrêt de la Cour d'arbitrage du 16 octobre 1991. Revue de Droit International et Droit Compare 87:24-56.

Popelier P. (1997) Rechtszekerheid als beginsel voor behoorlijke wetgeving (Legal certainty as a principle of proper lawmaking). Intersentia, Antwerp. 
Popelier P. (2005) Do instruments of direct democracy meet standards of democratic and proper law making? In: Mader L., Karpen U. (eds.) The participation of Civil Society in the Legislative Process. Nomos, Baden-Baden, pp. 101-118.

Popelier P. (2007) De visie van het Grondwettelijk Hof op de verhouding tussen de Grondwet en het internationale recht (The Constitutional Court's view on the relation between the Constitution and international law). Chroniques de droit public 14:228-238.

Popelier P. (2008) Procederen voor het Grondwettelijk Hof (Litigating before the constitutional court). Intersentia, Antwerp.

Popelier P. (2011) The supremacy dilemma: the Belgian Constitutional Court caught between the European Court of Human Rights and the European Court of Justice. In: Popelier P., Van de Heyning C., Van Nuffel P. (eds.) Human Rights Protection in the European Legal Order: the interaction between European and the national courts. Intersentia, Cambridge, pp. 149--172.

Popelier P. (2012) Judicial conversations in multilevel constitutionalism. The Belgian case. In: Claes M., Popelier P., De Visser M., Van de Heyning C. (eds.) Constitutional Conversations in Europe. Intersentia, Antwerp, pp. 73-100.

Popelier P. (2014a) Europe clauses and constitutional strategies in the face of multilevel governance. MJ 21:300-319.

Popelier P. (2014b) Subnational multilevel constitutionalism. Perspectives on Federalism 6:1-23.

Popelier P., Lemmens K. (2015) The constitutional system of Belgium. Hart, Oxford.

Popelier P., Van de Heyning C. (2011) Droits constitutionnels et droits conventionnels: concurrence ou complémentarité. In: Verdussen M. (ed.) Les droits constitutionnels en Belgique. Bruylant, Brussels, pp. 495-536.

Popelier P., Vandenbruwaene W. (2011) The subsidiary mechanism as a tool for inter-level dialogue in Belgium: on 'regional blindness' and cooperative flaws. EuConst 7:204-228.

Popelier P., Voermans W. (2015) Europeanization, constitutional review and consensus politics. In: Vollaard H., Beyers J., Dumont P. (eds.) European integration and consensus politics in the Low Countries. Routledge, Abingdon, pp. 92-113.

Raunio T. (2005) Holding governments accountable in European affairs: Explaining cross-national variation. The Journal of Legislative Studies 11:319-342.

Rimanque K. (2002) Samenstelling en bevoegdheden van een opnieuw hervormde Senaat (Composition and competences of the newly reformed Senate). In: Centre d'études constitutionnelles et administratives (ed.) Quelles réformes pour le Sénat? Bruylant, Brussels, pp. 73-77.

Rimanque K., Wouters J. (1998) De betekenis van de Grondwet voor de Europese rechtsorde (The importance of the Constitution for the European legal order). Tjeenk Willink, Zwolle.

Valticos N. (1984) Expansion du droit international et constitutions nationales, un cas significatif: le transfert de pouvoirs à des organisations internationales et la constitution Belge. In: Evolution constitutionnelle en Belgique et relations internationales. Hommage à $\mathrm{P}$. De Visscher. Pédone, Paris, pp. 9-22.

Van Assche C. (2012) Het Grondwettelijk Hof en het internationale recht: je t'aime, moi non plus? (The constitutional court and international law: je t'aime, moi non plus?). Revue belge de droit international 48:438-451.

Van de Heyning C. (2012) The European Perspective: from lingua franca to a common language. In: Claes M., Popelier P., De Visser M., Van de Heyning C. (eds.) Constitutional Conversations. Intersentia, Antwerp, pp. 181-204.

Van Meerbeeck J., Mahieu M. (2007) Traité international et constitution nationale. Rev. Crit. De Jurisprudence Belge 61:79-88.

Van Nuffel P. (2005) Het Europees recht in de rechtspraak van het Arbitragehof: prejudiciële vragen, te veel gevraagd? (European law in the case law of the Court of arbitration: preliminary references, asking too much? In: Alen A. (ed.) 20 jaar Arbitragehof. (20 years of the Court of Arbitration). Kluwer, Mechelen, pp. 38-47.

Van Nuffel P. (2010) Prejudiciële vragen aan het Hof van Justitie na het Verdrag van Lissabon (Preliminary references to the Court of Justice after the Lisbon treaty). Rechtskundig Weekblad 74:1154-1177. 
Vandamme T. (2008) Prochain Arrêt: La Belgique! Explaining recent preliminary references of the Belgian Constitutional Court. EuConst 4:127-148.

Vande Lanotte J., Goedertier G. (2010) Belgisch Publiekrecht (Belgian public law). Die Keure, Bruges.

Velaers J. (1999) De Grondwet en de Raad van State, afdeling wetgeving (The Constitution and the Council of State, Legal Branch). Maklu, Antwerp.

Velaers J. (2003) Artikel 190 van de Grondwet (Article 190 of the Constitution). In: Wintgens L. (ed.) De verplichting tot bekendmaking van de norm (The duty to publish legal norms). Die Keure, Bruges, pp. 31-70.

Velaers J. (2008) De samenloop van grondrechten in het Belgische rechtsbestel (Concurrence of fundamental rights in the Belgian legal order). In: Vereniging voor de vergelijkende studie van het recht van België en Nederland: Preadviezen 2008 (Association for the comparative legal study of Belgian and Dutch law: Preliminary reports 2008). Boom Juridische Uitgevers, The Hague.

Velaers J. (2012) The protection of fundamental rights by the Belgian Constitutional Court and the Melki-Abdeli judgment of the European Court of Justice. In: Claes M., Popelier P., De Visser M., Van de Heyning C. (eds.) Constitutional Conversations. Intersentia, Antwerp, pp. 323-342.

Velu J. (1992) Contrôle de constitutionnalité et contrôle de compatibilité avec les traités. Bruylant, Brussels.

Verrijdt W. (2012) Het Grondwettelijk Hof en het Unierecht: over constitutioneel pluralisme en rechterlijke dialoog (The Constitutional Court and Union law: on constitutional pluralism and judicial dialogue). In: Samoy I., Sagaert V., Terryn E. (eds.) Invloed van het Europese recht op het Belgische privaatrecht (Influence of European law on Belgian private law). Intersentia, Antwerp, pp. 41-100.

Verschueren H. (2011) Social federalism and EU law on the free movement of persons. In: Cantillon B., Popelier P., Mussche N. (eds.) Social Federalism: The Creation of a Layered Welfare State. Intersentia, Antwerp, pp. 211-223.

Weiler J.H.H. (1998) The European Court and National Courts, Doctrine and Jurisprudence. Hart Publishing, Oxford.

Wigny P. (1952) Droit constitutionnel. Principes et droit positif. Bruylant, Brussels.

Wouters J. (1998) De betekenis van de grondwet voor de Europese rechtsorde (The meaning of the constitution for the European legal order). W.E.J. Tjeenk Willink, Deventer.

Open Access This chapter is licensed under the terms of the Creative Commons Attribution 4.0 International License (http://creativecommons.org/licenses/by/4.0/), which permits use, sharing, adaptation, distribution and reproduction in any medium or format, as long as you give appropriate credit to the original author(s) and the source, provide a link to the Creative Commons license and indicate if changes were made.

The images or other third party material in this chapter are included in the chapter's Creative Commons license, unless indicated otherwise in a credit line to the material. If material is not included in the chapter's Creative Commons license and your intended use is not permitted by statutory regulation or exceeds the permitted use, you will need to obtain permission directly from the copyright holder. 